Efeitos da irradiância e da composição espectral da luz sobre o estabelecimento e desenvolvimento de comunidades de macroalgas lóticas em substratos artificiais

AURÉLIG FAJAR TINETTO

- Rio Claro -

Estado de São Paulo

Março de 2010 


\section{Efeitos da irradiância e da composição espectral da luz sobre o estabelecimento e desenvolvimento de comunidades de macroalgas lóticas em substratos artificiais}

Dissertação apresentada ao Instituto de Biociências do "Campus" de Rio Claro, Universidade Estadual Paulista, como parte dos requisitos para obtenção do grau de Mestre em Ciências biológicas (Área Biologia Vegetal)

Orientador:

Prof. Dr. Ciro Cesar Zanini Branco

- Rio Claro -

Estado de São Paulo

Março de 2010 
“Nossas dúvidas são traidoras e nos fazem perder o bem que poderíamos conquistar, se não fosse o medo de tentar"

(Veronica A. Shoffstall) 


\section{AGRADECIMENTOS}

Agradeço a Deus por me permitir viver as graças da vida.

Agradeço ao Prof. Dr, Ciro Cesar Zanini Branco por me mostrar o misterioso mundo das "plantinhas de riacho", por trazer inspiração nas suas tão empolgadas discussões sobre algum resultado interessante, e principalmente, por ser além de um grande orientador, um grande amigo.

Agradeço aos meus queridos pais, José Roberto e Ana Luisa, por estarem sempre tão próximos mesmo tão distantes, por acreditarem em mim e, principalmente, por terem construído uma nobre família da qual tenho muito orgulho de fazer parte, além de fazer questão que pessoas queridas a mim os conheçam justamente por que seria muito triste para tais pessoas não terem a oportunidade de saborear as qualidades deste casal tão especial.

Agradeço ao amor de minha vida, Tati, por dedicar a sua vida a nós, por estar sempre ao meu lado, e por mostrar a mim que não a nada mais gostoso do que sonhar com uma vida ao lado da pessoa que você ama. Você me da um sentido a vida.

Agradeço aos meus queridos irmãos, Felipe e Tássia, Larissa e Aninha, pelos estudos juntos, pelas guerrinhas com tesouras, pelos duelos no Fifa, pelas casinhas de camas, cintadas, melancia, provas, desenhos, viagens, e muitas outras coisas. Mas principalmente por fazerem parte da minha vida, tornando-a incrível diante de pessoas tão especiais.

Agradeço aos meus incríveis amigos irmãos Dri, Neves, Quinzinho, Rô primão e Reinaldo pelas piadas, pelas noites sem dormir jogando God of War, Call of Duty ou Quake, pelos cinemas, pelas longas e intermináveis conversas, pelas partidas de pingpong, pelas baladas, mas simplesmente por me mostrarem que verdadeiras amizades continuam a crescer mesmo a longas distâncias. A falta destes B S é muito grande.

Agradeço a Ricardo (Richard), Gabriel (Pesquisa), Kadu, Carnero e Gustavo (Goiano), amigos de laboratório e graduação, por me mostrarem que não vai existir outra turma como a nossa e que nunca é tarde para se encontrar verdadeiros amigos.

Agradeço a Marcão Knifes, não é assim que se escreve, por ser mais do que um grande amigo. Por ser uma honra tê-lo como amigo, e estar seguindo a mesma estrada juntos. Pelas divertidas partidas de Fifa, músicas e incríveis conversas sobre o mundo. Um grande irmão.

Agradeço ao Prof. Dr. Pitagoras Bispo, pelas valiosas dicas e ensinamentos, pela amizade e por torcer por mim, "o homem dos experimentos".

Agradeço a Gustavo (Bixíssimo) e Tiago (Espanta), alunos de graduação em Assis, pela incrível ajuda nas viagens de monitoramento do trabalho, tornando as expedições mais agradáveis e divertidas na companhia de pessoas tão parceiras e amigas.

Agradeço em especial ao grande amigo irmão Cleto Kaveski Peres pela sua simplicidade e companheirismo, pelos deliciosos ensopados de batata, pelos seus valiosos ensinamentos, discussões e, principalmente, por ser um privilégio ser amigo de uma pessoal tão especial. Sua ajuda foi essencial.

A CAPES, pela bolsa concedida. 


\section{Sumário}

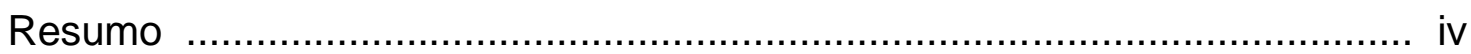

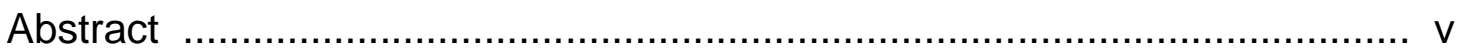

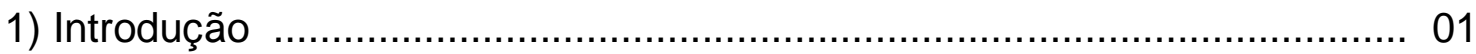

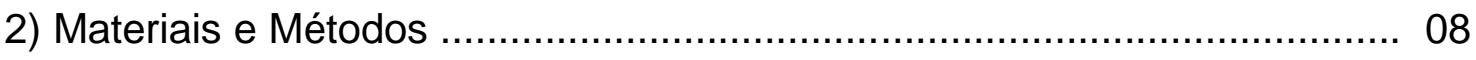

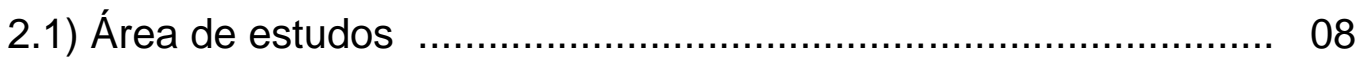

2.2) Montagem dos amostradores e descrição dos experimentos ..... 09

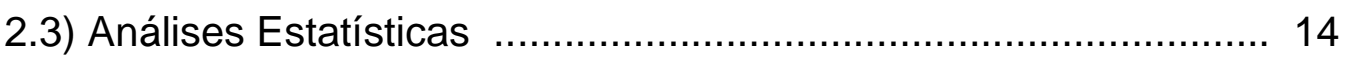

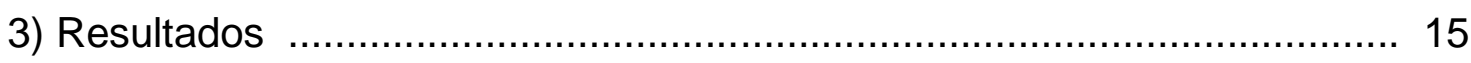

3.1) Tratamentos envolvendo a variação quantitativa da luz ............ 16

3.2) Tratamentos envolvendo a variação qualitativa da luz $\ldots \ldots \ldots \ldots \ldots . . . .17$

3.3) Variação temporal das comunidades de macroalgas lóticas $\ldots 18$

3.3.1) Variação temporal - tratamentos envolvendo a variação quantitativa da luz .................................................... 19

3.3.2) Variação temporal - tratamentos envolvendo a variação qualitativa da luz ............................................................ 20

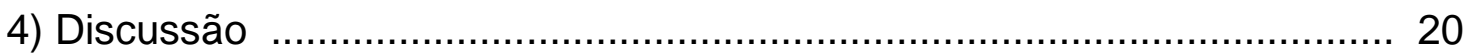

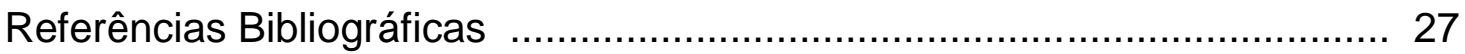

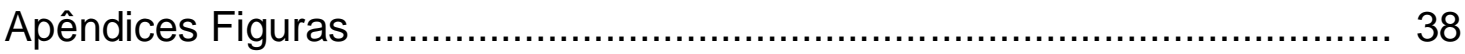




\section{Resumo}

Os efeitos provocados pela variação quantitativa e qualitativa da luz incidente sobre a estrutura das comunidades de macroalgas lóticas em riachos da região Centro-Sul do estado do Paraná foram investigados a partir de experimentos utilizando-se amostradores com substratos artificiais que modulam a quantidade e qualidade da luz incidente. Os resultados reveleram que as respostas das divisões algais isoladamente foram mais claras do que àquelas observadas para as comunidades de macroalgas como um todo. As algas verdes mostraram-se melhores adaptadas as condições com maiores energias luminosas. A espécie de cianobactéria registrou clara preferência por comprimentos de onda mais longos (faixa do vermelho). As algas vermelhas apesar de apresentarem baixos valores de abundância, aparentemente, preferiram condições levemente sombreadas e, como as cianobactérias, apresentaram maiores valores de abundância quando submetidas a luz vermelha. Neste contexto, o aparato fotossintético característico de cada divisão algal parece ser determinante para os seus comportamentos ecológicos, uma vez que desempenham funções adaptativas diante das diferentes condições de luminosidade.

Palavras chave: macroalgas lóticas; quantidade de luz; qualidade de luz; Estado do Paraná. 


\begin{abstract}
The effects of light intensity and quality on the structure of lotic macroalgal communities in streams from the mid-southern region of Paraná State were investigated using artificial substrata that simulate different levels of light and specific wavelengths. The results showed that the abundance values of each algal divisions were clearer to that observed to global macroalgae communities. The green algae were better adaptated on higher light energies conditions. The cianobacteria species reported a clear preference to longer wavelengths (red light). Red algae, on the other hand, despite of the low abundance values, apparently prefer lightly shaded conditions and like blue-green algae, they showed better colonization on the red light. In this context, the characteristic photosynthetic apparatus of each division seems to be determinant to the ecological behavior of these communities once they play an important adaptative role face to the different light conditions.
\end{abstract}

Key words: lotic macroalgae, light intensity, light quality, Paraná State. 


\section{1) Introdução}

Águas correntes compõem o principal fator físico ambiental que descreve os ambientes lóticos e, ao mesmo tempo, o distingui de ambientes lênticos (Maitland, 1990). Tal condição confere, aos ambientes lóticos, diversas características peculiares que garantem a existência de um ecossistema extremamente particular (Hynes, 1970; Maitland, 1990). O fluxo unidirecional constante, por exemplo, elimina gradientes verticais na coluna d’água comumente observados em ambientes lacustres, exceto para variável ambiental luz (Lampert \& Sommer, 2007). Rios e riachos fornecem diversos tipos de habitats para os organismos aquáticos, diferentemente de outros corpos d’água, pois estão sujeitos a modificações estruturais ao longo do seu percurso, o que consequentemente provoca grandes variações nas propriedades físicas e químicas do ambiente (Round, 1965). Além disso, a erosão é uma característica mais presente em ambientes de águas correntes do que em ambientes lênticos, o que torna mais intenso o fluxo de materiais e nutrientes (Maitland, 1978). Quanto a biota, a grande movimentação da água impede a ocorrência de organismos tipicamente planctônicos, exceto em rios de grande porte com baixa velocidade da correnteza (Reynolds et al., 1991), o que favorece o estabelecimento de uma comunidade bentônica mais rica e exuberante.

De fato, além das adaptações correspondentes aos fatores controladores como flutuações espaciais e temporais de inúmeros parâmetros físicos e químicos (Round, 1983; Gordon et al., 1992; Allan, 1995), o principal descritor desses ambientes, fluxo da correnteza, compõem um fator seletivo muito poderoso ao qual os organismos lóticos devem estar necessariamente adaptados, para garantir assim, o desenvolvimento e manutenção das populações de uma maneira relativamente estável (Giller \& Malmqvist, 1998). Dessa forma, em virtude do conjunto de características adaptativas e ambientais associadas, principalmente, a correnteza da água, as comunidades com características bentônicas compõem os organismos que obtiveram o maior sucesso nestes ambientes, tornando-se a porção biótica esmagadoramente dominante. Este fato se deve, fundamentalmente, a sua capacidade de 
associação com o substrato, o que permite a sua permanência no ambiente e melhor aproveitamento dos recursos disponíveis (Lampert \& Sommer, 2007).

Entretanto, Ward (1989) comenta que a heterogeneidade espaçotemporal dos ecossistemas lóticos vai além da correnteza e, na verdade, se desenvolve em resposta a processos dinâmicos ocorrendo ao longo de um mosaico interativo em quatro dimensões: a longitudinal, que constitui interações desde a montante até a jusante do rio, envolvendo transporte de efluentes ou migração de indivíduos; a lateral, que inclui as trocas de matérias e energia entre o canal do riacho e a vegetação marginal, a qual pode modular a entrada de luz e fornecer uma grande quantidade de matéria orgânica alóctone; a vertical, que por sua vez, reflete a conexão entre o canal e as águas subterrâneas próximas, considerando que há comunicação física entre as águas superficiais e subsuperficiais; e, por fim, a temporal, que envolve mudanças previsíveis e não previsíveis ao longo de uma escala de tempo que sobrepõem as três dimensões do espaço (Ward, 1989; Giller \& Malmqvist, 1998). Como exemplo, a Hipótese do Distúrbio Intermediário de Connell (1978) é estruturada com base no efeito da dimensão temporal exercido no ecossistema lótico e, a Hipótese do Continuo Fluvial (Vannote et al., 1980) nos efeitos da dimensão longitudinal.

Os produtores primários, facilmente observados nas comunidades bentônicas destes ambientes, são organismos que adquirem sua própria energia a partir da energia luminosa e recursos não vivos (Allan \& Castillo, 2007). Os principais produtores em águas correntes incluem representantes do grupo das cianobactérias, todas as algas eucarióticas, e vegetais superiores, exceto gimnospermas. Somando-se a este fato, algumas bactérias e protistas também possuem importante papel como autótrofos em águas correntes (Allan \& Castillo, 2007).

Em particular para estes organismos produtores da comunidade bentônica, o componente ficológico tem sido amplamente descrito como um dos principais elementos de sustentação da cadeia alimentar destes ambientes (Lamberti, 1996). Neste sentido, todos os substratos que estejam recebendo luz, seja em pequenos riachos ou em um rio de grande porte, sustentam uma comunidade de algas bentônicas (Allan \& Castillo, 2007). Tais comunidades 
removem nutrientes da coluna d`água, atenuam a correnteza e a estabilidade dos sedimentos, promovendo, assim, uma modificação do habitat aquático (Stevenson, 1996; Dodds \& Biggs, 2002). Entretanto, esta comunidade ficológica pode estabelecer-se sob diferentes formas e arranjos. Uma importante porção da flora algal é constituída por espécies que apresentam crescimento macroscópico evidente, ou seja, são visíveis e reconhecíveis em campo a olho nu (John \& Moore 1985, Sheath et al., 1986; 1989), sendo tradicionalmente reportadas como macroalgas lóticas (Sheath \& Cole, 1992).

Importante ressaltar neste momento a inevitável sobreposição entre a comunidade perifítica com a de macroalgas, uma vez que ambas fazem parte da porção bentônica dos ambientes lóticos. Em primeiro lugar, a história da terminologia associada às comunidades microbianas aderidas aos substratos é longa e cheia de inconsistências e redundâncias (Wetzel, 1983). Isto se deve a variada natureza dos substratos e organismos componentes. O termo perifíton foi utilizado primeiramente por Behning em 1924, para definir os organismos aderidos a substratos artificiais submersos na água. Posteriormente, a designação foi estendida para todos os organismos aquáticos que crescem em superfícies submersas. A partir deste raciocínio, diversas outras definições foram construídas na tentativa de conceitualizar definitivamente este tipo próprio de comunidade (Cooke, 1956; Sládecková, 1962; Round, 1964). Todavia, somente em 1983, Robert Wetzel conseguiu agrupar algumas das características diagnósticas destes organismos, de modo a efetivar a definição do termo perifíton com aceitação na comunidade científica. Perifíton é um termo comumente utilizado para se referir a complexa comunidade de microorganismos associada ao substrato, incluindo, assim, microalgas, fungos, bactérias ou mesmo animais. Stevenson (1996), de acordo com esta breve definição, comenta que macroalgas não poderiam, então, ser consideradas perifíton, fato este confirmado pela posterior definição do termo macroalgas proposto por Sheath \& Cole (1992), na qual há explicita separação destas em relação as microalgas.

Neste contexto, entretanto, diversos estudos ainda referem-se as macroalgas como comunidades perifíticas ou, simplesmente perifíton (Biggs, 1990; DeNicola, 1992; Trundeau \& Rasmussen, 2003). Esta sobreposição 
explica-se pela evidente coexistência destes organismos no ambiente em que habitam, tornando-se perfeitamente compreensível que os limites entre os componentes micro (perifíton) e macroscópico (macroalga) sejam extremamente difícieis de se estabelecerem. Assim, o ponto fundamental a ser cuidadosamente trabalhado a partir desta constatação é a metodologia empregada, que deve estar coerente com as peculiaridades da comunidade abordada.

As comunidades de macroalgas lóticas, a que se refere este estudo, são recorrentemente relacionadas com muitas variáveis ambientais determinantes da sua composição e estrutura, seja em relação a distribuição, abundância ou riqueza das espécies (Esteves, 1988; Allan, 1995). Entre as principais variáveis pode-se citar: temperatura da água (Necchi \& Pascoaloto, 1993; Branco, 1995; 1996), turbidez (Necchi \& Pascoaloto, 1993; Branco, 1995; 1996; 2003), tipo de substrato (Sheath et al. 1989; Stock \& Ward, 1991; Pfister,1993; Branco, 2003), condutividade específica (Branco, 1995; Leukart, 1995; Sherwood \& Sheath, 1999), oxigênio dissolvido (Necchi \& Pascoaloto, 1993; Branco, 1994; 1995; Branco, 2003; Foerster et al., 2004), sombreamento (Sheath et al. 1986; Necchi et al. 2003), profundidade (Necchi et al. 2003; Pfister,1993; Sherwood \& Sheath, 1999), velocidade da correnteza (Necchi et al., 1994; Sherwood \& Sheath, 1999; Necchi et al. 2003;) e, nutriente dissolvidos (Entwisle, 1990; Leukart, 1995; Foerster et al., 2004).

Estas variáveis ambientais podem ser categorizadas como fatores controladores do desenvolvimento das algas bentônicas (seja micro ou macroscópica) regulando processos de ganho e de perda de biomassa (Stevenson, 1996). Particularmente, a perda de biomassa é liderada por processos de distúbios, geralmente associados a altas velocidades da correnteza e abrasão de sedimentos suspensos (Stevenson, 1996). Para o ganho de biomassa, por sua vez, os níveis de luminosidade compõem um dos principais fatores de grande influência.

Neste contexto, a irradiância é claramente imprescindível para a realização dos processos fotossintéticos em organismos autotróficos e, dessa forma, tem sido amplamente descrita como um dos principais fatores determinantes da estrutura e função das comunidades de algas lóticas 
bentônicas no que diz respeito a biomassa (Steinman \& Mclntire, 1987; Steinman et al., 1989), produtividade (Bott et al., 1985; King \& Cummins, 1989), e composição taxonômica (Lyford \& Gregory, 1975, Shoetreed \& Stockner, 1983; Steinman \& Mclntire, 1987). DeNicola et al. (1992) dizem que as propriedades ópticas da vegetação ripária e da coluna d’água compõem a principal influência na disponibilidade da luz nesses ambientes. Assim, adaptações ao sombreamento devem ser consideradas cruciais para determinar como as algas de riachos respondem às constantes mudanças do regime de luz, tanto no espaço quanto no tempo (Hill et al., 2001).

A luz pode ser estudada considerando-se a quantidade (irradiância), qualidade (composição espectral), e duração, aspectos que são detectados pelas plantas no decorrer de seu desenvolvimento (Batschauer, 1998). Neste sentido, diversos estudos têm procurado investigar as respostas da comunidade algal quando submetidas a diferentes condições de luminosidade (Hill et al., 1995; Roberts et al., 2004; Rier et al., 2006). Entretanto, a grande maioria desses trabalhos envolve a irradiância, ou seja, o aspecto quantitativo da luminosidade (Rier et al., 2006; Hill et al., 1995; Roberts et al., 2004). De fato, a quantidade de luz influência profundamente a fotossíntese de modo que a taxa fotossintética pode ser várias vezes maiores em locais abertos do que em locais fechados (Hill, 1995). Em riachos, por exemplo, a biomassa algal correlaciona com o grau de preservação da vegetação ripária (Hill \& Harvey, 1990).

O papel da composição espectral (qualidade da luz), por sua vez, tem sido muito pouco estudado e os trabalhos realizados não promoveram grandes evidências sobre o efeito de comprimentos de onda específicos (Antoine \& Benson-Evans, 1983a; 1983b; Prézelin et al., 1991; Stevenson, 1996). Contudo, há estudos que sugerem uma forte relação entre a composição espectral e o comportamento ecológico das comunidades algais. Sheath \& Burkholder (1985) comentam que a vegetação riparia absorve comprimentos de onda na faixa do azul e vermelho, e a luz verde resultante, pouco utilizada pela clorofila a, explicaria a ausência de algas verdes em tais condições. Ainda, para algas marinhas, uma teoria proposta por Engelmann sugere que as algas estariam distribuídas na coluna da água em respostas aos diferentes 
comprimentos de onda que as atingem, e estes determinariam seus conteúdos pigmentares (Saffo, 1987; Lobban \& Harrison, 1997)

O conteúdo pigmentar pode estar diretamente relacionado a variações da irradiância ou composição espectral recebidas pela alga (Honsell et al., 1984; Carnicas et al., 1999; Guimarães, 2000). Diferenças nas respostas sobre o efeito da luz para a maioria das divisões algas têm sido sugeridas devido a estas categorias terem, em parte, diferenças justamente na composição qualitativa e quantitativa dos pigmentos fotossintetizantes (Stevenson, 1996). Embora exista uma considerável variabilidade interespecífica dentro dos grupos taxonômicos, algumas evidências para o fitoplâncton indicam que há, de fato, diferenças entre as grandes divisões.

Entretanto, as comunidades algais reportadas na maioria destes trabalhos são normalmente não macroscópicas, restringindo-se as comunidades perifíticas (Hill \& Harvey, 1990; Hill et al., 1995) e fitoplanctônicas (Rivkin, 1989), sendo ainda as condições de luminosidade simuladas geralmente em laboratório. Tais trabalhos ainda, mesmo aqueles poucos que envolvam macroalgas, abordam, na sua maior parte, aspectos ecofisiológicos (Falkowski \& LaRoche, 1991; Necchi, 2004; Pfannschmidt, 2005) buscando entender processos celulares e não o seu comportamento ecológico, particularmente os fenômenos que determinam a dinâmica populacional deste grupo de organismos.

Para ampliar o conhecimento e, consequentemente, melhorar a compreensão sobre o comportamento ecológico das macroalgas lóticas diante das variáveis ambientais, sejam físicas, químicas ou temporais, diversos estudos têm utilizado estratégias metodológicas que envolvem o uso e aplicação tanto de critérios de amostragem a partir da avaliação das comunidades algais dispostas em substratos naturais (Sládecková, 1962; Wetzel, 1965; Soares, 1981) como em substratos artificiais (Castenholz, 1961; Cattaneo et al., 1975; Panitz, 1980). Hentschel em 1916 foi quem primeiro utilizou lâminas de vidro e outros tipos de substratos para estudos tanto qualitativos como quantitativos do perifíton (Sládeková, 1962). Desde então, numerosos estudos passaram a ser realizados mediante utilização de substratos artificiais (Schwarzbold, 1990). 
Tais substratos não naturais são bastante usados em estudos ecológicos por apresentarem menor dificuldade no manuseio das amostras e proporcionarem a criação de situações que permitem a possibilidade de serem, posteriormente, testadas e comparadas com o ambiente natural. Exemplos de estudos ecológicos envolvendo a análise de comunidades de produtores associadas a substratos artificiais em ambientes lóticos são relativamente comuns na literatura mundial (Biggs, 1988; Liaw \& Maccrimmon, 1978; Leland \& Carter, 1985; Clifford et al., 1992; Barbee, 2005). Vários estudos semelhantes são encontrados para rios e riachos brasileiros (Lobo \& BuselatoToniolli, 1985; Oliveira et al., 2002; Mendes \& Barbosa, 2002; Fernandes \& Esteves, 2003; Skinner \& Coutinho, 2005; Lobo et al., 2004). Entretanto, a absoluta maioria destas investigações foi dedicada a comunidades perifíticas (sensu Wetzel, 1983), envolvendo a análise dos seus componentes microscópicos. Trabalhos com abordagens semelhantes envolvendo, particularmente, a porção macroscópica das comunidades de produtores neste ambientes, em especial as macroalgas (sensu Sheath \& Cole, 1992), são raríssimos. No Brasil, apenas um único estudo foi realizado até o presente momento (Branco et al., submetido a publicação). Neste trabalho, os autores, que avaliaram o desenvolvimento da biomassa e da riqueza de espécies de macroalgas lóticas em função do tipo de substrato artificial e do tempo de exposição, concluíram que os tipos de substratos (vidro, acrílico e cerâmica) e de texturas (lisa ou rugosa) não interferiram significativamente no desenvolvimento tanto da abundância quanto da riqueza de espécies que os colonizaram.

Considerando os argumentos expostos acima, o presente estudo foi conduzido para abordar aspectos ecológicos das comunidades de macroalgas em amostradores com substratos artificiais que simulam diferentes tipos de irradiâncias. Neste sentido, além de investigar os efeitos da luz sobre as macroalgas a partir de simulações de diferentes níveis de intensidade luminosa, variações na composição espectral foram adicionadas com o objetivo de construir novas informações, principalmente, em se tratando de macroalgas lóticas. De uma maneira geral, portanto, procurou-se, neste estudo, avaliar os efeitos provocados pela variação quantitativa (irradiância) e qualitativa 
(composição espectral) da luz incidente sobre a estrutura das comunidades de macroalgas lóticas em riachos da região Centro-Sul do estado do Paraná, a partir de experimentos utilizando-se amostradores com substratos artificiais.

Os objetivos específicos do presente estudo foram: 1) analisar a influência de diferentes níveis de irradiância no desenvolvimento de biomassa, riqueza e composição de espécies das comunidades de macroalgas lóticas (estudo quantitativo); 2) analisar a influência de composições espectrais específicas da luz sobre o desenvolvimento de biomassa, composição florística e riqueza das espécies de macroalgas lóticas (estudo qualitativo); 3) estudar a variação temporal das comunidades de macroalgas lóticas sob diferentes condições de luminosidade (quantitativa e qualitativa); e, por fim, 5) ampliar os conhecimentos ecológicos sobre as comunidades de macroalgas de ambientes lóticos, particularmente, brasileiros.

\section{2) Materiais e Métodos}

\section{1) Área de estudo}

O estudo sobre as comunidades de macroalgas, a que se refere este trabalho, realizou-se na Bacia do Rio das Pedras situada no município de Guarapuava, região Centro-Sul do Estado do Paraná entre as latitudes

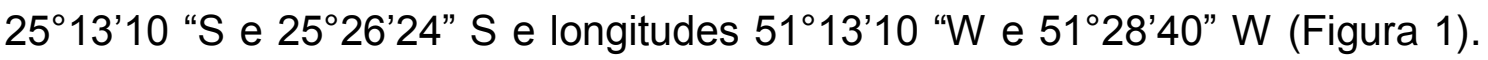
Tal região é rica em riachos e estudos prévios (Krupek et al., 2007; Krupek et al., 2008a; 2008b) constataram uma boa presença de representantes algais (Chlorophyta, Cyanophyta e Rhodophyta).

A área da Bacia do Rio das Pedras apresenta-se constituída basicamente pela Floresta Ombrófila Mista, classificada como alto Montana, ou seja, localizada acima de 1000 metros de altitude (IBGE, 1992). Atualmente a cobertura vegetal na bacia está bastante modificada, em termos de composição e distribuição espacial, em relação aos seus padrões originais. Não há nessa área nenhum remanescente de uma floresta em condições originais. Existe um mosaico de situações em que predominam remanescentes 
florestais de pequena área com níveis sucessionais, entre primários e secundários.

O clima de Guarapuava é classificado como subtropical mesotérmico úmido - sem estação seca, com verões frescos e inverno moderado. A pluviosidade mostra-se bem distribuída ao longo do ano, com precipitações médias anuais em torno de $1960 \mathrm{~mm}$, apresentando variações extremas consideráveis e a temperatura média anual fica em torno de 16 a $17,5{ }^{\circ} \mathrm{C}$ (Thomaz \& Vestena, 2003).

De uma forma geral, a alta quantidade de águas correntes, presença de algas e pluviosidade bem distribuída ao longo do ano, que evidencia uma menor ocorrência de fenômenos de enchentes, torna a área excelente para a realização de experimentos envolvendo macroalgas lóticas.

Embora a região não tenha uma época correspondente à estação seca, o período escolhido para a realização do trabalho foi aquele com menores precipitações pluviométricas. Período este verificado como o de maior riqueza e abundância de espécies de macroalgas lóticas em regiões tropicais (Sheath \& Burkholder, 1985; Necchi \& Pascoaloto, 1993).

A escolha dos riachos onde foram instalados os experimentos levou em consideração os seguintes critérios: i) profundidade suficiente para a submersão completa dos amostradores contendo os substratos artificiais; ii) presença de substrato rochoso predominante e iii) intensidade luminosa que atinge a coluna d'água o mais próximo de $100 \%$ da luz disponível no ambiente. Esta característica foi fundamental, pois, assim foi possível simular os diferentes tipos de atenuação da luz (quantitativa e qualitativa) criados pelos experimentos.

Entre diversos riachos analisados, quatro riachos foram selecionados (Figura 2) (Rio das Pedras, Rio Lajeado e Rio das Mortes, Rio Guabiroba).

\section{2) Montagem dos amostradores e descrição do experimento}

Os amostradores utilizados nos experimentos foram construídos com peças acrílicas soldadas formando um tubo de seção quadrada medindo, aproximadamente, $15 \mathrm{~cm}$ de comprimento, $8 \mathrm{~cm}$ de largura e $8 \mathrm{~cm}$ de altura 
(Figura 3A e 3B). No interior dos tubos utilizados nos experimentos foi instalada uma placa plana de vidro rugosa (Branco et al., submetido a publucação) removível com $15 \mathrm{~cm}$ de comprimento e $8 \mathrm{~cm}$ de largura, que foram, de fato, os substratos utilizados para se avaliar as respostas qualitativas e quantitativas das comunidades de macroalgas.

A atenuação luminosa e a seleção da composição espectral sobre o desenvolvimento das comunidades de macroalgas foram produzidos pela aplicação de películas redutoras da luminosidade solar sobre as paredes externas dos amostradores. Simão et al. (2008) estudando a germinação de sementes de plantas da família Asteraceae utilizaram estas películas redutoras da irradiância e concluiram que, aparentemente, elas produzem um efeito de seleção de comprimento de ondas similar ao produzido pela cobertura vegetal natural.

Os amostradores foram acoplados a placas de concreto com aproximadamente $17 \mathrm{Kg}$, as quais serviram como ancoras, a fim de manter os amostradores, ao máximo, em uma posição estável ao longo de todo o experimento. Além disso, amarras de ferro foram utilizadas para prender as placas de concreto em estruturas associadas as margens dos riachos (quase sempre troncos e galhos) de modo a evitar possíveis movimentações.

O planejamento experimental tomou cuidados especiais para evitar ao máximo a perda do trabalho em virtude de eventuais enchentes ou atividades antrópicas, além de buscar o melhor método que manipulasse a variável física em investigação e ao mesmo tempo mantivesse as outras condições do ambiente o mais semelhante possível entre os tratamentos. Assim, o delineamento selecionado atendeu ao princípio estatístico do controle local para a realização do estudo. Tal princípio corresponde ao delineamento de "blocos ao acaso ou casualizados", com cada bloco possuindo uma repetição de cada um dos tratamentos, permitindo, portanto, um melhor controle da variação ambiental (Centeno et al., 1999). Segundo Cochram \& Cox (1950) esse tipo de planejamento apresenta uma maior precisão que experimentos inteiramente casualizados, pode ser utilizado com qualquer número de tratamentos ou repetições e a análise estatística é simples. 
Para se avaliar os dados mediante estatística formal, os estudos foram conduzidos conforme o programa amostral descriminado a seguir.

Os quatro riachos são, estatisticamente, equivalentes aos blocos. Em cada bloco (riacho) foi instalada uma repetição de todos os tratamentos. Os tratamentos, por sua vez, foram dispostos aleatoriamente, por meio de um sorteio, em cada um dos blocos (riachos).

O experimento contou com sete grupos amostrais: um controle (sem aplicação de película) e seis tratamentos, sendo estes últimos distinguidos em duas categorias: 1) tratamentos quantitativos (irradiância), em que foram testadas a atenuação da intensidade luminosa, com o uso de películas redutoras da luminosidade (atenuação de 50\%, 70\% e 90\%); e 2) tratamentos qualitativos (composição espectral), em que foram avaliados comprimentos de ondas específicos da irradiância (aplicação de películas das cores azul, verde e vermelho). As películas redutoras de luminosidade utilizadas foram da marca Insulfim $^{\mathrm{TM}}$, linha automotiva Insulfilm Climatizado. A composição espectral de cada película foi fornecida pelo grupo de pesquisa do Laboratório de Fisiologia Vegetal UNESP-Rio Claro (Figura 4). A Tabela 1. mostra a quantidade de luz em cada um dos tratamentos de luz.

Tabela 1. Valores da quantidade de irradiância em cada um dos tratamentos de luz investigados no experimento.

\section{Tratamentos}

Controle

$50 \%$ de atenuação

$70 \%$ de atenuação

$90 \%$ de atenuação

Azul

Verde

Vermelho
Quantidade ( $\left.\mu \mathrm{mol} . \mathrm{m}^{-2} \cdot \mathrm{s}^{-1}\right)$

$904,2 \pm 59,6$

$471,0 \pm 44$

$300,3 \pm 37,6$

$89,2 \pm 14,9$

$533,1 \pm 69,3$

$357,9 \pm 34,4$

$417,4 \pm 43,3$ 
Os tratamentos foram utilizados em quadruplicatas, produzindo um total de 28 amostradores.

A instalação dos amostradores nos riachos foi realizada no dia 09 de abril de 2009, que corresponde ao início do período mais favorável para o desenvolvimento das comunidades de macroalgas de regiões tropicais, ou seja, fim da primavera a início do outono (Necchi \& Pascoaloto, 1993). A definição do tempo de duração do experimento se baseou em informações de estudos prévios, envolvendo testes de colonização realizados tanto para comunidades perifíticas (Fernandes \& Esteves, 2003; Lobo \& Buselato-Toniolli, 1985) como para comunidades de macroalgas (Branco et al., em preparação, Necchi \& Alves, comunicação pessoal) e também pelas observações feitas no próprio ambiente. Assim, o experimento apresentou duração de 91 dias, período suficiente para uma colonização adequada para as análises condizentes com os objetivos do trabalho.

O experimento foi visitado em intervalos de aproximadamente quinze dias, compondo um conjunto de nove visitas. Durante esses monitoramentos foi realizada a coleta de dados bióticos e abióticos para se adquirir informações temporais do ambiente lótico em investigação.

Estudos de experimentação envolvendo comunidades autotróficas, sejam elas perifíticas ou de macroalgas, avaliam as respostas da comunidade algal por uma série métodos amplamente aceitos e utilizados (Wetzel, 1981; Wetzel, 1983). Dois dos mais empregados métodos são: a extração de clorofila a (Marker et al., 1980; Sartory \& Grobbellar, 1984) e a quantificação de massa seca e/ou massa seca livre de cinzas (Schwarzbold et al.,1990). Em trabalhos de campo, por outro lado, a distribuição de macroalgas em uma determinada área ou região, é analisada frequentemente pela "técnica da transeção" associada a estimativa visual da abundância através da quantificação da porcentagem de cobertura destas no ambiente.

Contudo, apesar de muito utilizados e aceitos, a exatidão desses métodos é apenas relativa. A avaliação da biomassa baseada na massa seca e/ou massa seca livre de cinzas torna-se relativamente imprecisa, uma vez que pela própria definição da porção macroscópica da comunidade algal (Sheath \& Cole, 1992), esta inclui outros organismos, algais e não algais, associados ao 
seu talo. Do mesmo modo, em uma análise envolvendo a quantidade de pigmentos fotossintetizantes (clorofila a), a relação dessas substâncias pode ser significativamente alterada. A técnica da estimativa visual da cobertura percentual empregada nos trabalhos de campo, por sua vez, é da mesma forma problemática, já que esta, sendo extremamente dependente dos observadores, poderá, eventualmente, diferir entre eles.

Neste contexto, o presente trabalho buscou aprimorar a avaliação da biomassa das comunidades algais, quantificando, especificamente, as macroalgas de ambientes lóticos. Para isso, empregou-se uma técnica similar a utilizada em outras áreas de pesquisa científica, como, por exemplo, aquelas que avaliam a estimativa da área foliar de plantas (Godoy et al., 2007; RicoGarcia et al., 2009) ou mesmo da cobertura do dossel de uma área florestada (Canham, 1988; England, 2000). Tais estudos fundamentam-se na técnica baseada em análises de fotografias digitais, metodologia esta nunca empregada em estudos ecológicos envolvendo comunidades de macroalgas lóticas.

Assim, em cada visita aos pontos de experimentação as placas de vidro do interior dos amostradores foram removidas individualmente e registros fotográficos foram realizados com o auxilio de uma máquina digital da marca Canon Modelo Powershot A630 8.0 Megapixels. As posições dos espécimes encontrados em cada placa foram mapeadas em gabaritos de papel sulfite, nos seus respectivos tratamentos, de modo a facilitar a análise a posteriori das fotografias digitais obtidas. O processo durou menos de cinco minutos até que as placas retornassem aos amostradores de forma a evitar danos a comunidade algal, por exemplo, por ressecamento.

Os valores de abundância, então, foram avaliados através da quantificação da porcentagem de cobertura do substrato a partir de análises computacionais das fotografias. As fotos de cada um dos amostradores foram analisadas com o auxílio do software AutoCad versão 2008. Para isso, as áreas superficiais cobertas com "manchas" de cada uma das espécies de algas foram marcadas, e, então, calculadas as porcentagens de cobertura em relação a área total do substrato. Tal método confere uma maior precisão da área ocupada pela flora de macroalgas, o que representa uma grande 
vantagem em relação a técnica de estimativa visual, comumente aplicada. Apesar da análise de porcentagem de cobertura ser um método semiquantitativo, ele não é destrutivo, o que garante a ausência de perda de biomassa algal, sendo assim o mais apropriado para quantificar a abundância ao longo do tempo.

Além dos dados biológicos, as seguintes variáveis físicas e químicas da água foram mensuradas com um controlador de qualidade da água Horiba U10: temperatura, turbidez, oxigênio dissolvido, potencial hidrogeniônico $(\mathrm{pH})$ e condutividade com uma amostra de água do próprio local. Além dessas variáveis, os seguintes parâmetros ambientais também foram medidos: velocidade da correnteza, tomada o mais próximo possível da superfície de cada um dos amostradores, utilizando-se um correntômetro eletrônico Swoffer 3000; e, por fim, a irradiância, registrada junto aos amostradores, com o auxílio do quantômetro Li-Cor LI-189, com sensor de quantum esférico Li-Cor LI193SA. Tal medida foi tomada por volta das 12 horas no dia de instalação. Durante os monitoramentos, por sua vez, a irradiância não foi mensurada, pois a diferença de horário entre as análises de um riacho para o outro era muito grande, o que levaria a mensurações equivocadas.

Tanto os dados biológicos como abióticos foram coletados durante os monitoramentos. Juntamente com a coleta desses dados, a parede de acrílico dos amostradores foi levemente escovada para eliminar o perifiton que colonizava a superfície dos mesmos e evitar, portanto, uma atenuação da luz, incidente nas placas de vidro.

\section{3) Análises Estatísticas}

Os dados físicos, químicos e biológicos referentes as condições ambientais e aos valores de abundância dos tratamentos foram inicialmente submetidos a estatística descritiva. Em seguida, análises de variância com medidas repetidas (ANOVA medidas repetidas) com teste Tukey a posteriori foi usada para comparar a abundância das assembléias de macroalgas e a abundância isolada das divisões algais nos diferentes tempos de colonização, com blocos e tratamentos de luz como variáveis independentes e tempo de 
exposição como variáveis dependentes. Além disso, foram aplicadas análises de Regressão Linear Mútipla (Sokal \& Rohlf, 1981) para avaliar o efeito do conjunto das variáveis ambientais sobre a abundância, de modo a identificar possíveis informações explicativas sobre a dinâmica temporal da comunidade.

O programa utilizado para as análises estatísticas foi STATISTICA, versão 7.0 e a construção dos gráficos foi realizada no programa MicrosoftExcel, versão 2007.

\section{3) Resultados}

A partir da metodologia descrita anteriormente, foi possível extrair informações interessantes sobre as respostas da comunidade de macroalgas lóticas sob o efeito quantitativo e qualitativo da variável luz. Portanto, para melhor apresentação dos resultados, as informações encontradas serão relatadas de forma fragmentada para facilitar a observação dos dados obtidos. Assim, serão apresentados: i) tratamentos envolvendo a variação na quantidade de luz, ii) tratamentos envolvendo a variação na qualidade de luz e, iii) variação temporal das comunidades de macroalgas nesses tratamentos de luz (quantitativo e qualitativo).

As flutuações das variáveis físicas e químicas mensuradas durante 0 experimento estão representadas graficamente na Figura 5. A análise de regressão múltipla entre as variáveis ambientais revelou uma fraca correlação positiva entre os níveis de precipitação e a velocidade da correnteza, mas não significativa (beta $=0,566$ ). Embora o experimento tenha sido realizado, de fato, em um período de menor precipitação pluviométrica para a região, os valores desta variável foram relativamente altos, o que provocou uma consequente elevação da velocidade da correnteza (Figura 5). Os valores de abundância global registrados para cada tratamento foram extremamente baixos e, revelaram, por análise de regressão múltipla, uma forte e negativa correlação com a pluviosidade (com maior valor de beta $=-1,044, p>0,01$ ).

As espécies registradas no estudo estão listadas na Tabela 2. Importante salientar que o gênero de cianobactéria registrado no trabalho, devido a complicada taxônomia do táxon, não foi identificado com a devida 
segurança. Dessa forma, a representante da divisão Cyanophyta foi tratada simplesmente como cianobactéria. A espécie Draparnaldia mutabilis, por sua vez, foi encontrada em apenas uma réplica e somente em uma data ao longo de todo o experimento. Sendo assim, esta espécie foi desconsiderada das análises estatísticas.

Tabela 2. Lista de espécies encontradas no experimento.

\section{Espécies de macroalgas encontradas Ocorrência nos riachos}

\begin{tabular}{ll}
\hline Cianobactéria & $\begin{array}{l}\text { Rio Pedras, Mortes, Lajeado e } \\
\text { Guabiroba }\end{array}$ \\
Tetraspora lubrica (ROTH) C. AGARDH & Rio Pedras, Mortes, Lajeado \\
$\begin{array}{ll}\text { Draparnaldia mutabilis (ROTH) BORY } \\
\text { Batrachospermum puiggarianum } \\
\text { GRUNOW in WITTROCK \& } \\
\text { NORDSTEDT }\end{array}$ & Rio Lajeado \\
\hline
\end{tabular}

\section{1) Tratamentos envolvendo a variação quantitativa da luz (irradiância)}

Os dados de abundância média das comunidadse de macroalgas como um todo diante dos diferentes tratamentos envolvendo o nível de atenução da irradiância estão apresentados na Figura 6A. Neste gráfico é possível observar que o tratamento controle apresentou valor médio de abundância maior que todos os outros tratamentos. Entretanto, o tratamento com 50\% de atenuação da irradiância, apesar de graficamente menor que o tratamento controle, registrou valores de abundância, para algumas réplicas, muito maiores do que o tratamento controle. É possível observar ainda uma clara tendência inversamente proporcional entre a abundância de macroalgas e a atenuação da irradiância de modo que nos tratamentos de maior atenuação, a cobertura percentual da comunidade foi menor. No entanto, a análise estatística não captou diferenças significativas entre estes tratamentos. A distribuição de freqüência dos valores de abundância também revela uma diminuição da ocorrência de maiores valores da abundância com o aumento da atenuação da luz (Figura 7A) 
Somando-se aos resultados anteriores, algumas considerações podem ser levantadas sobre as repostas particulares das divisões algais. A divisão Cyanophyta, em particular, (Figura 8A) não apresentou interferência na sua colonização diante dos níveis de atenuação da irradiância testados, com valores muito baixos e semelhantes de percentual de cobertura entre os tratamentos e, portanto, sem diferenças significativas entre eles. Chlorophyta (Figura 9A), por outro lado apresentou uma forte tendência inversamente proporcional ao aumento da atenuação da irradiância. Por fim, a divisão Rhodophyta (Figura 10A), apresentou valores muito baixos de abundância, inclusive no tratamento controle.

3.2) Tratamentos envolvendo a variação qualitativa da luz (Composição espectral)

Para estes tratamentos as respostas da comunidade de macroalgas estão representadas graficamente na Figura 6B. Para as análises com a comunidade como um todo, o grupo controle mais uma vez atingiu valores de abundância superiores aos tratamentos, embora não significativo. Entre os tratamentos, os valores de abundância foram muito próximos entre si revelando uma fraca influência da variação qualitativa da luz sobre o desenvolvimento da comunidade de macroalgas. Por outro lado, em uma análise mais profunda dos dados, a freqüência de ocorrência dos valores de abundância entre esses tratamentos revelou que cerca de $85 \%$ das amostragem realizadas no tratamento verde registrou valores extremamente baixos de abundância contra aproximadamente $60 \%$ para os tratamentos azul e vermelho (Figura 7B).

A divisão Cyanophyta isoladamente (Figura 8B) revelou uma das tendências mais evidentes do experimento. Nestes tratamentos, os valores de abundância de cianobactérias foram bem maiores no tratamento vermelho e diferiram estatisticamente dos outros grupos experimentais, incluindo 0 tratamento controle e os tratamentos quantitativos $(F=3,6001, p<0,05)$. Os tratamentos azul e verde foram semelhantes ao controle com baixos valores de percentual de cobertura. Chlorophyta (Figura 9B), por sua vez, registrou maiores valores de cobertura para os tratamentos controle e azul. Entretanto, 
apesar destas considerações, é importante salientar que não foram notificadas diferenças estatisticamente significativas para esta divisão entre os tratamentos envolvidos no experimento de variação qualitativa da luz. As algas vermelhas (Figura 10B), representadas pela espécie Batrachospermum puiggariannum, revelaram resultado semelhante às cianobactérias, com maiores valores de abundância no tratamento com luz vermelha, mas como ocorreu em apenas um riacho, não foi possível realizar analise estatística para esta divisão.

\section{3) Variação Temporal das comunidades de macroalgas}

A colonização temporal da comunidade de macroalgas lóticas esta representada graficamente na Figura 11. Neste gráfico é possível observar que a comunidade apresentou o maior valor de abundância na quarta data de coleta (03.v.09), ou seja, com 23 dias após a instalação dos amostradores nos riachos. A partir desse momento os valores passaram a oscilar levemente entre $1,5 \%$ e $2 \%$ até o final do experimento. Segundo a ANOVA com medidas repetidas e teste Tukey a posteriori a data 23.iv.09 diferiu das outras datas ( $\mathrm{F}=$ $6,44354 p<0,001)$.

Os grupos taxonômicos, por sua vez, diante da variação temporal (Figura 12 e 13) revelaram, que em regra, as algas verdes apareceram antes das cianobactérias. Para o caso particular do Rio Lajeado, único que registrou representantes da divisão Rhodophyta, foi observado um maior desenvolvimento destas nos estágios finais do experimento. Este resultado foi semelhante às cianobactérias, com uma diferença: as algais vermelhas no Rio Lajeado registraram algumas ocorrências esporádicas em estágios mais recentes do processo temporal, ocorrência esta, não observada entre as algais azuis, restritas aos estágios finais.

Um aspecto interessante observado neste estudo foi a grande semelhança entre as composições florísticas dos amostradores artificiais, de modo que as espécies encontradas no estudo foram exatamente iguais entre os quatro riachos investigados, exceto para Batrachospermum puiggarianum, que ocorreu exclusivamente no Rio Lajeado. Ainda nesse contexto, a estratégia de fixação das macroalgas presentes no experimento foi esmagadoramente 
representada por espécimes incrustantes, ou seja, espécies associadas intimamente ao substrato.

\subsection{1) Variação Temporal - tratamentos envolvendo a variação} quantitativa da luz (irradiância)

O desenvolvimento da comunidade macroalgal ao longo do tempo revelou um resultado interessante quando considerados os tratamentos envolvendo a variação da quantidade de luz. A Figura 14A mostra que houve uma clara diminuição gradativa nos valores de abundância de macroalgas com o aumento da atenuação luminosa. Enfaticamente, o tratamento com $90 \%$ de atenuação da irradiância registrou, em 100\% das coletas, valores extremamente baixos de cobertura porcentual (Figura 14A). A cobertura percentual da comunidade de macroalgas atingiu o pico dos valores na coleta do dia 03.v.09 e, a partir deste período ocorreu uma redução da biomassa em todas as réplicas. Importante salientar que, de modo geral, o gradiente entre os tratamentos se manteve relativamente constante ao longo do período de estudo, a não ser por uma alteração nos estágios finais. Neste momento, os tratamentos com 50\% e 70\% de atenuação apresentaram maior biomassa do que o tratamento controle.

A divisão Cyanophyta (Figura 15A) apresentou, durante todo o período de experimentação, valores baixíssimos de abundância com um leve aumento da cobertura percentual na parte final do experimento para todos os tratamentos, sem nenhuma diferença clara entre eles. Chlorophyta (Figura 16A), por sua vez, foi muito semelhante com o padrão verificado para a comunidade como um todo, uma vez que a contribuição das algas verdes na abundância total foi expressiva. Assim, claramente os valores de cobertura percentual foram maiores nos tratamentos com menor atenuação da intensidade luminosa. A divisão Rhodophyta (Figura 17A), semelhante as cianobactérias, apresentou maiores abundâncias nos estágios mais tardios do experimento, sendo que o maior valor foi registrado para o tratamento com $50 \%$ de atenuação. 
3.3.2) Variação Temporal - tratamentos envolvendo a variação qualitativa da luz (Composição espectral)

Diferentemente dos tratamentos com diferentes níveis quantitativos de luz, as respostas das comunidades de macroalgas diante dos tratamentos qualitativos ao longo do tempo não foram muito claras (Figura 14B). Isto se deve ao fato da grande oscilação dos tratamentos de maior abundância ao longo do tempo. O tratamento verde, com baixos valores de abundância em estágios iniciais, terminou o experimento como sendo o mais abundante. $O$ grupo experimental azul, por sua vez, apresentou tendência inversa ao tratamento verde, iniciando o experimento como um dos mais abundantes e terminando como um dos menos abundantes. $O$ tratamento vermelho revelou um aumento relativamente contínuo da abundância com o passar do tempo experimental, finalizando o estudo como sendo o tratamento mais abundante.

Considerando os grupos taxonômicos individualmente, algumas respostas tornaram-se mais evidentes. O resultado para a divisão Cyanophyta (Figura 15B) foi seguramente o mais notório. Esse grupo taxonômico, em especial para o tratamento vermelho, revelou um claro acréscimo contínuo no seu percentual de cobertura ao longo do tempo, muito diferente dos outros tratamentos, incluindo os quantitativos. Chlorophyta (Figura 16B) foi, novamente, similar aos resultados de abundância global observados para a comunidade de macroalgas, exceto para o tratamento vermelho. As algas vermelhas (Figura 17B), por sua vez, apresentaram um resultado semelhante às cianobactérias, com um leve aumento dos valores de abundância no final do estudo, especificamente no tratamento vermelho.

\section{4) Discussão}

A ocorrência das espécies presentes no experimento apresentou alta semelhança entre os tratamentos investigados nos quatro riachos utilizados. Apesar de ter ocorrido a espécie B. puiggariannum somente no Rio Lajeado, a espécie representante da divisão Chlorophyta (Tetraspora lubrica) e a espécie de cianobactéria foram exatamente as mesmas nos quatro riachos. Por outro 
lado, diversos estudos, realizados no Brasil, envolvendo a distribuição de macroalgas lóticas de amplas regiões, têm sugerido a ocorrência restrita das espécies em virtude das características locais do riacho (Branco et al., 2009; Sheath et al., 1989). No entanto, Borges \& Necchi (2006) em trabalho sobre padrões de distribuição espacial de comunidade de macroalgas lóticas registraram alta semelhança entre o conjunto de espécies de riachos de uma mesma região, sugerindo que a predominância das espécies é provavelmente influenciada por fatores regionais. Esta condição é similar a encontrada neste estudo, já que os riachos investigados encontram-se em uma mesma região, além de possuírem características parecidas entre si como, por exemplo, a alta incidência de luz.

Além disso ainda, tais espécies apresentaram tipos morfológicos muito semelhantes, sendo de pequeno porte e com grande capacidade de aderência ao substrato, podendo ser classificados como estrategistas $r$ (sensu Biggs, 1998). Segundo Biggs (1998), os atributos gerais que descrevem os estrategistas $r$ são: boa resistência a distúrbios físicos, pequeno tamanho, baixa biomassa, grande capacidade de aderência ao substrato, com predomínio de formas adnatas e formas com mucilagem tipo almofada basal. Em outras palavras, estas informações são muito coerentes para as espécies registradas neste estudo. Uma possível explicação para o grande predomínio deste tipo funcional pode estar na relativa alta freqüência de chuvas com conseqüente aumento da velocidade da correnteza. As formas filamentosas, de estágios mais tardios do processo sucessional (Hoagland et al., 1982), ocorreram esporadicamente em, provavelmente, curtos períodos de relativa estabilidade do habitat. Neste sentido, a variação no regime de precipitação, e seus efeitos consequentes sobre a estabilidade dos habitats lóticos parecem ser antes de tudo muito importantes. Esta constatação vem sendo ampla e recorrentemente corroborada por estudos ecológicos de comunidade de macroalgas de diversas naturezas.

Apesar dos baixos valores de abundância global registrados, a variação desta medida ao longo do tempo apresentou-se muito semelhante ao padrão universal descrito para algas bentônicas de riachos. Stevenson (1996) explica que o tempo que a comunidade atinge o pico de biomassa pode variar de 2 
semanas em ambientes com baixas intensidades de distúrbios, a até 70-100 dias em ambientes com severos distúrbios. As comunidades de macroalgas investigadas neste estudo parecem estar muito próximas deste padrão, mas, talvez possam não ter atingido seu pico de biomassa real. Como todos os tratamentos estavam submetidos às mesmas condições ambientais, é importante salientar que as considerações reportadas acima são válidas para todas as réplicas de todos os tratamentos testados.

Apesar da grande semelhança entre as espécies e seus respectivos tipos morfológicos, é notável algumas distinções entre o desenvolvimento temporal da comunidade de macroalgas sob o efeito dos diferentes tratamentos de luminosidade. Ficou evidente, por exemplo, que a quantidade de luz incidente sobre a comunidade limitou, de fato, o acúmulo de biomassa por parte destas. O tratamento com $90 \%$ de atenuação, diferentemente dos outros tratamentos quantitativos, não seguiu o mesmo padrão de desenvolvimento, registrando, na verdade, uma quase ausência de crescimento algal. Ainda, o tratamento com maior quantidade de luz apresentou rápido crescimento. Sendo assim, estes resultados corroboram estudos prévios que comprovam que a luz atua, de fato, como um fator controlador da produtividade e ganho de biomassa (e.g. Bothwell, 1988; 1989; Boston \& Hill, 1991). Entretanto, um aspecto importante a ser discutido refere-se ao fato do tratamento com $70 \%$ de atenuação ter apresentado, ocasionalmente, valores de abundância global maiores do que os tratamentos com maior irradiância. Tal ocorrência pode ser, pelo menos em parte, atribuída a uma possível adaptação a condição de sombreamento ou fotoaclimatação (Falkowski \& LaRoche, 1991) da comunidade de macroalgas. Esta adaptação manifesta um aumento da eficiência fotossintética em baixos níveis de luz e menores taxas fotossintéticas em luz saturante, uma mudança funcional que reflete o aumento da quantidade de pigmentos fotossintetizantes e a diminuição de reações de enzimas do escuro. Poucos estudos tem documentado tal fenômeno, porém, Mclntire \& Phinney (1965) encontraram que a comunidade perifítica obteve maior taxa fotossintética em $40 \mu \mathrm{mol} \mathrm{m} \mathrm{m}^{-2} \mathrm{~s}^{-1}$ de irradiância do que a comunidade submetida a $110 \mu \mathrm{mol} \mathrm{m} \mathrm{m}^{-2} \mathrm{~s}^{-1}$. 
Além disso, a fotoinibição é um fenômeno fisiológico que também pode explicar este comportamento. Antoine \& Benson-Evans (1983b) dizem que altos níves de luz podem compor um efeito prejudicial para as células algais reduzindo seu conteúdo pigmentar e, assim, reduzindo sua taxa fotossintética. Hill \& Boston (1991) encontraram que o perifiton de locais sombreados apresentou fotoinibição quando submetidos a altos valores de irradiância (1100 $\mu \mathrm{mol} \mathrm{m} \mathrm{m}^{-2}$ ).

Com relação aos tratamentos com a variação da composição espectral da luz, para abundância global, algumas considerações podem ser salientadas. Nestes experimentos, os dados mostraram que o tratamento vermelho apresentou valores médios de abundância maiores devido, principalmente, a maior abundância de cianobactérias. Além disso, este tratamento apresentou, em regra, um ganho crescente de biomassa ao longo do tempo. O tratamento verde, por sua vez, registrou maior freqüência de valores baixos de abundância. Stevenson, (1996) comenta que as folhas das árvores da vegetação ripária absorvem fortemente os comprimentos de ondas azuis e vermelhos, filtrando para o riacho maior quantidade de luz verde, que é pobremente absorvida pelas clorofilas a e b. Sheath \& Burkholder (1985) sugerem que a ausência de algas verdes em ambientes sujeitos ao sombreamento de uma densa vegetação ripária ocorra devido a sua falta de pigmentos acessórios que absorvam eficientemente a luz verde. Neste contexto, os resultados revelaram uma aparente incoerência, no momento em que, em alguns casos, há o registro de maiores valores de biomassa justamente no tratamento verde. Entretanto, tal resultado pode ser explicado pelo fato das películas utilizadas no tratamento verde e azul apresentarem comprimentos de ondas no espectro de irradiância levemente sobrepostos (Figura 4), permitindo uma possível passagem de luz azul, que é, conforme Stevenson (1996) melhor absorvida pelos pigmentos fotossintéticos.

Para as divisões algais isoladamente pode-se observar algumas respostas diferenciadas. Para o táxon representante da divisão Cyanophyta, não foi observado nenhum tipo de preferência diante dos diferentes níveis de intensidade de luz, revelando, talvez, uma fraca influência da irradiância sobre o desenvolvimento de biomassa neste grupo de algas. Antoine \& Benson- 
Evans (1983b) encontraram que Oscillatoria tenuis cresceu indiferentemente nos tratamentos com a luz branca. Contudo, outros trabalhos têm sugerido que esta divisão seria melhor adaptada a menores irradiâncias (Langdon, 1988; Hill, 1996). Necchi (2004) classificou o grupo das cianobactérias como intermediário em relação a sua resposta a diferentes intensidades de luz. Neste sentido, aliás, Necchi et al. (2008) comentam que o predomínio de cianobactérias em ambientes lóticos do Estado do Rio de Janeiro e Minas Gerais, foi, provavelmente, devido a sua adaptação a diferentes tipos de sombreamento, tanto abertos como sombreados.

$\mathrm{Na}$ análise temporal, por sua vez, foi observado que estas algas desenvolveram-se melhor nos estágios finais do estudo, entretanto sem revelar preferências evidentes diante dos tratamentos com variação quantitativa da luz. Talvez, tais diferenças possam não ter sido captadas devido aos baixos valores de abundância.

Diante das diferentes composições espectrais, a cianobactéria apresentou forte preferência pelo tratamento de luz vermelha, fato também reportado por Antoine \& Benson-Evans (1983b). Isso deve ter ocorrido, provavelmente, em função do seu conjunto característico de pigmentos fotossintetizantes. Esta divisão possui pigmentos acessórios específicos que auxiliam a otimizar o processo fotossintético (Marsac, 1977) e tais pigmentos, conhecidos como ficobiliproteínas, absorvem diferentes faixas de luz, sendo as mais freqüentes c-ficoeritrina (com máximo de absorbância em $\approx 565 \mathrm{~nm}$ ), ficoeritrocianina ( $\approx 570 \mathrm{~nm})$, c-ficocianina $(\approx 620 \mathrm{~nm})$ e aloficocianina $(\approx 650 \mathrm{~nm})$ (Grossman et al., 1993). O processo pelo qual as cianobactérias alteram a composição quantitativa de suas ficobiliproteínas em resposta a diferentes comprimentos de ondas do espectro de irradiância é denominado de adaptação cromática (Bogorad, 1975; Tandeau de Marsac, 1983; Grossman, 1990). No presente estudo, foi observado maior abundância de cianobactérias no tratamento com comprimentos de ondas mais longos (600 a $700 \mathrm{~nm}$ ), ou seja, na faixa em que ocorre maior absorbância em ficocianinas e aloficianinas. De fato, Diakoff \& Scheibe (1973) para Tolipotrix tenuis e Haury \& Bogorad (1977) e Vogelman \& Scheibe (1978) para Fremyella diplosiphon registraram máxima síntese de ficocianinas entre 650 e $660 \mathrm{~nm}$. Sendo assim, existe, portanto, 
evidencias na literatura de que o grupo das cianobactérias apresentam maior eficiência na absorção de comprimentos de ondas na faixa da luz vermelha, informação muito coerente com o resultado deste experimento. Por fim, foi considerável o maior desenvolvimento dessas algas também nos tratamentos de luz vermelha, durante a variação temporal, o que corrobora os resultados anteriores.

A divisão Chlorophyta, por sua vez, registrou uma tendência inversamente proporcional ao aumento da atenuação da luz, ou seja, muito semelhante a abundância global já que as algas verdes compuseram maior parte dela. De modo geral, as Chlorophyta apresentaram maiores colonizações no grupo controle, ou seja, aquele com maior incidência luminosa. Na literatura há vários trabalhos que apresentam tendências absolutamente semelhantes ao observado neste estudo. Richardson et al. (1983) concluíram que algas verdes não toleram, de fato, baixas intensidades luminosas como cianobactérias e diatomáceas. Outros estudos como Langdon (1988) e Steinman \& Maclntire (1987) também chegaram à mesma conclusão de que a divisão Chlorophyta realmente torna-se mais abundante apenas em altas intensidades de luz. Necchi (2004), em estudo ecofisiológico, encontrou que espécies de Chlorophyta são algas tipicamente de sol devido a altos valores de $I_{k}$ e falta ou baixo níveis de fotoinibição. Assim, os resultados encontrados neste presente estudo corroboram tais informações. Entretanto, assim como já reportado anteriormente, a fotoaclimatação e fotoinibição também podem explicar o fato do grupo experimental $70 \%$ ter registrado maiores valores de abundância de algas verdes que o controle e $50 \%$. A variação temporal das algas verdes foram semelhantes àquela observada para abundância global.

Nos tratamentos com diferentes comprimentos de onda as algas verdes apresentaram maiores valores de abundância no grupo controle e no tratamento azul. Estes resultados podem ser explicados pelo fato deste grupo taxonômico possuir, entre os pigmentos acessórios, carotenóides ( $\beta$-caroteno) que protegem o aparato fotossintético destas algas contra os efeitos danosos da luz (Demming-Adams \& Adams, 1992). Assim, as algas verdes poderiam ter maior eficiência fotossintética mesmo submetidas a luz azul, um comprimento de onda mais curto e, portanto, mais energético. Wallen (1970) registrou, para 
algas marinhas uma maior taxa de crescimento em comprimento de onda na faixa do azul em comparação com a luz branca e verde.

Por fim, a divisão Rhodophyta, apresentou uma resposta, para a irradiância, semelhante as algas verdes e, para a variação espectral da luz, similar as cianobactérias, porém, com algumas peculiaridades. Igualmente às Chlorophyta, as algas vermelhas apresentaram uma variação na abundância inversamente proporcional ao aumento da atenuação (para o tratamento Controle, com maior quantidade de luz, elas registraram baixo valor de abundância) evidenciando assim que este grupo algal possui, de fato, uma tendência a ocorrer em ambientes com menores intensidades luminosas (Leukart \& Hanelt, 1995; Necchi \& Zucchi, 2001; Necchi, 2004). Assim, de modo geral, os tratamentos com atenuação registraram as maiores biomassas para estas algas, ou seja, em condições de sombreamento. As algas vermelhas têm sido frequentemente caracterizadas como sendo adaptadas a condições de menores quantidades de luz (Hynes, 1970). Porém outros estudos têm indicado que este grupo habita uma variedade de regimes luminosos (Stevenson, 1996). Necchi (2004) em estudos ecofisiológicos, encontrou que as Rhodophyta foram consistentemente aclimatadas à baixas irradiâncias e classificou este grupo como tipico de ambientes sombreados. Branco \& Necchi (1996), em trabalho sobre a distribuição de macroalgas no Estado de São Paulo, comentam que a predominância relativa das Rhodophyta na Mata Atlântica ocorreu, provavelmente, pelo fato destas algas serem melhores representadas em locais mais sombreados do que as algas verdes e, explicam que a quantidade e qualidade da luz poderiam ser fatores importantes para explicar a competição nestes riachos.

Para a composição espectral, por sua vez, a resposta deste grupo foi similar àquela encontrada para as cianobactérias, ou seja, maior biomassa no tratamento vermelho. A divisão Rhodophyta apresenta complexo pigmentar semelhante aos das algas azuis com a presença de ficobiliproteínas, porém, dentro de cloroplastos (Lee, 2008). Neste contexto, Cole \& Sheath (1990) dizem que os efeitos da qualidade da luz que ocorrem sobre o aparato fotossintético de cianobactérias devem afetar de maneira semelhante os componentes fotossintéticos das algas vermelhas. 
Em resumo, a variação da luz, seja ela quantitativa (irradiância) ou qualitativa (composições espectrais especificas) mostrou relevante influência sobre o desenvolvimento das comunidades de macroalgas lóticas. Porém, os tratamentos que envolveram a variação da quantidade de luz apresentaram, aparentemente, maior efeito para a abundância global da comunidade, enquanto que os tratamentos qualitativos, por sua vez, revelaram uma influencia mais pronunciada para as divisões algais específicas.

\section{Referências Bibliográficas}

ALLAN, D.J. 1995. Stream Ecology: structures and functions of running waters. Lodon: Chapman \& Hall, 388p.

ALLAN, J.D. \& CASTILLO, M. M. Stream Ecology: structure and functions of running waters. $2^{\underline{a}}$ edition. Springer, Dordrecht. 2007.

ANTOINE, S.E. \& BENSON-EVANS, K. 1983a. The effect of light intensity and quality on the growth of benthic algae. L Phytopigment variations. Archiv für Hydrobiologie. 98: 299-306.

ANTOINE, N.H., AND K. BENSON-EVANS.1983b. The effect of light intensity and quality on the growth of benthic algae. II. Population dynamics. Archiv fur Hydrobiologie 99:118-128.

BARBEE, N.C. 2005. Grazing insects reduce algal biomass in a neotropical stream. Hydrobiologia 532:153-165

BATSCHAUER, A. 1998. Photoreceptors of higher plants. Planta 206: 479-492.

BIGGS, B.J.F. 1988. A periphyton sampler for shallow, swift rivers. New Zealand Journal of Marine and Freshwater Research 22:189-199.

BIGGS, B.J.F. 1990. Periphyton communities and their enviroments in New Zealand rivers. New Zeal. J. Mar. Freshw. Res. 24, 367-386.

BIGGS, B.J.F. et al. 1998. A habitat matrix conceptual model for stream periphyton. Arch. Hydrobiol., Stuttgart, 143(1): 21-56.

BOGORAD, L. 1975. Phycobiliproteins and complementary chromatic adaptation. Annu. Rev. Plant Physiol. 26:369-401. 
BOSTON, H.L. \& HILL, W.R. 1991. Photosynthesis-light relations of stream periphyton communities. Limnology and Oceanography. 36: 644-654.

BOTHWELL M.L. 1988. Growth rate responses of lotic periphytic diatoms to experimental phosphorus enrichment: the influence of temperature and light. Canadian Journal of Fisheries and Aquatic Sciences. 45: 261-270.

BOTHWELL, M.L. 1989. Phosphorus-limited growth dynamics of lotic periphytic diatom communities: areal biomass and cellular growth rate responses. Canadian Journal of Fisheries and Aquatic Sciences. 46: 1293-1301.

BORGES, F.R.; NECCHI, O.Jr. 2008. Short-term successional dynamics of a macroalgal community in a stream from northwestern São Paulo State, Brazil. Acta Botanica Brasilica, v. 22, p. 453-463.

BOTT, T.L. BROCK, J.T. DUNN, C.S. NAIMAN, R.J. OVINK, R.W. \& PETERSON, R.C. 1985. Benthic community metabolism in four temperate stream system: an inter-biome comparison and evaluation of the river continuum concept. Hydrobiologia. 123: 3-45.

BRANCO, C.C.Z. 1995. Aspectos florísticos e ecológicos das comunidades de macroalgas de riachos da região oriental de Mata Atlântica do Estado de São Paulo. Dissertação de Mestrado, Rio Claro, IB,UNESP. 108 p.

BRANCO, L.H.Z. ; SANTANNA, C.L. ; SILVA, S. M. F. 1994. Stichosiphon mangle sp. nova, a new cyanophyte from mangrove environment. Algological Studies. 72:1-7.

BRANCO, C.C.Z. \& NECCHI, O.Jr. 1996. Survey of stream macroalgae of eastern Atlantic Rainforest of São Paulo State, southeastern Brazil. Arch. Hydrobiol. 80: 35-57.

BRANCO, C.C.Z. \& NECCHI, O.Jr. 2003.Temporal dynamics of two species of Chaetophoraceae (Chlorophyta) in tropical streams of São Paulo State, southeastern Brazil. Rev. Brasil. Bot. 26(2): 151-161.

BRANCO, C.C.Z., BRANCO, L.H.Z., MOURA, M. O. \& BERTUSSO, F. R. 2005. The sucession dynamics of a macroalgal community after a flood disturbance in a tropical stream from São Paulo State, southeastern Brazil. Revista Brasileira de Botânica, São Paulo, v. 28, p. 267-275.

BRANCO, C.C.Z., KRUPEK, R.A. \& PERES, C.K. 2009. Distribution of stream macroalgal communities from the mid-western region of Paraná state, southern Brazil: importance of local scale variation. Brazilian Journal of Biology and Technology. 52(2): 379-386. 
BORGES, F.R., NECCHI, O.Jr. 2006. Patterns of spatial distribution in macroalgal communities from tropical lotic ecosystems. Revista Brasileira de Botânica. 29: 669-680.

CANHAM, C.D. 1988. An index of understory light levels in and around canopy gaps. Ecology 69, pp. 1634-1703.

CASTENHOLZ, R.W. 1961. The Effect of Grazing on Marine Littoral Diatom Populations. Ecology 42:783-794.

CATTANEO, A., GHITTORI, S. \& VENDEGNA, V. 1975. The development of benthonic phytocenosis on artificial substrates in the Ticiano river. Oecologia 19:315-327.

CENTENO, A.J., KRATZ, F.L., VALVA, F.D., MONTEIRO, M.S.R., TORRES, R.A.A. \& CHEN, L.C. 1981. Curso de estatística aplicada a biologia. $1^{a}$ edição. Editora UFG, Goiânia, GO.

CLIFFORD, H.F., CASEY R.J., SAFFRAN K.A. 1992. Short-term colonization of rough anh smooth tiles by benthic macroinvertebrates and algae (chlorophyll a) in two streams. Journal of the North American Benthological Society, 11: 304315.

COCHRAM, W.G. \& COX, G.M. 1950. Experimental desings. New York, John Wiley \& Sons.

COLE, K.M. SHEATH, R.G. Biology of the red algae. Cambridge University Press. New York. 1990.

CONNEL, J.H. 1978. Diversity in tropical rain forest and coral reefs. Science, New York, 199: 1302-1309.

COTTINGHAM, K.L., CARPENTER, S.R., AMAND, A.L.S.T. 1998. Responses of epilimnetic phytoplankton it experimental nutrient en three small seepage lakes. J. Plankton. Res. 20(10): 1889-1914.

DeNICOLA, D.M. 1996. Periphyton responses to temperature at different ecological levels. In: STEVENSON, R.J., BOTHWELL, M.L., LOWE, R.L. (eds): Algal ecology - freshwater benthic ecosystems. - Academic Press, San Diego. p. $150-181$.

DIAKOFF, S. \& SCHEIBE, S. 1973. Action spectra for chromatic adaptation in Tolypothrix tenuis. Plant Physiol. (Bethesda) 51: 382-385.

DODDS, W.K, BIGGS, B.J.F. 2002. Water velocity attenuation by stream periphyton and macrophytes in relation to growth form and architecture. Journal of the North American Benthological Society 21: 2-15. 
ENGLUND, S.R., O'BRIEN, J.J. \& CLARK, D.B. 2000. Evaluation of digital and film hemispherical photography and spherical densiometry for measuring forest light environments. Can. J. For. Res. 30, pp. 1999-2005.

ENTWISLE, T.J. 1989. Macroalgae in Yarra River basin: flora and distribution. Proc. Royal Soc. Victoria 101: 1-76.

ESTEVES, F.A. 1988. Fundamentos de Limnologia. Rio de Janeiro: Editora Interciência/FINEP, 575p.

FALKOWSKI, P.G. \& LAROCHE, J. 1991. Acclimation to spectral irradiance in algae. Journal of Phycology. 27: 8-14.

FERNANDES, V.O. \& ESTEVES, F.A. 2003. The use of índices for evaluating the periphytic community in two kinds of substrate in Imbioassica Lagoon, Rio de Janeiro, Brazil. Brazilian Journal of Biology 63:1-16.

FOERSTER, J., GUTOWSKI, A. \& VIS, M.L. 2004. Defining types of running waters in Germany using benthic algae: A prerequisite for monitoring according to the Water Framework Directive. Journal of Applied Phycology, Dordrecht. 16: 407-418.

GODOY, L.J.G., YANAGIWARA, R.S. BÔAS, R.L.V., BACKES, C. \& LIMA, C.P. 2007. Análise da imagem digital para estimativa da área foliar em plantas de laranja "Pêra". Revista Brasileira de Fruticultura. 29 (3): 420-424.

GORDON, N.D., McMAHON, T.A. \& FINLAYSON, B.L. 1992. Stream hydrology: an introduction for ecologists. Chichester: John Wiley \& sons, 526p.

GILLER, P.S. \& MALMQVIST, B. 1998. The Biology of stream and rivers: biology of habitat. Oxford: Oxford University Press, 296p.

GLOSSÁRIO de Ecologia. 1997, 2. Ed. Ver. e. Ampli. ACIESP, São Paulo, 352 pp. (Publicação ACIESP, n. 103).

GROSSMAN, A.R., SCHAEFER, M. R., CHIANG, G. G. \& COLLIER, J. R.1993. Environmental effects of light-harvesting complex of Cyanobacteria. Journal of Bacteriology. 175(3): 575-582.

GROSSMAN, A.R. 1990. Chromatic adaptation and the events involved in phycobilisome biosynthesis. Plant Cell Environ. 13:651-666.

HAURY, J.F., \& BOGORAD, L. 1977. Action spectra for phycobiliprotein synthesis in a chromatically adapting cyanophyte. Plant Physiology. (Bethesda) 60: 835-839. 
HILL, W.R., \& BOSTON, H.L. 1991. Community development alters photosynthesis-irradiance relations in stream periphyton. Limnology and Oceanography. 36: 1375-1389.

HILL, W.R. \& HARVEY. 1990. Periphyton responses to higher trophic levels and light in a shaded stream. Canadian Journal of Fisheries and Aquatic Sciences. 47: 2307-2314.

HILL, W.R. MULHOLLAND, P.J. \& MARZOLF, E.R. 2001. Stream ecosystem responses to forest leaf emergence in spring. Ecology. 82: 2306-2319.

HILL, W.R., RYON, M.G. \& SCHILLING, E.M. 1995. Light limitation in a stream ecosystem: responses by primary producers and consumers. Ecology. 76(4):1297-1309.

HOAGLAND, K.D., ROEMER, S.C. \& ROSOWSKI, J.R. 1982. Colonization and community structure of two periphyton assemblages, with emphasis on the diatoms (Bacillariophyceae). American Journal of Botany. 69(2): 188-213.

HYNES, H.B.N. 1970. "The ecology of running waters." University of Toronto Press, Toronto, 555p.

JOHN, D.M. \& MOORE, J.A. 1985. Observations on the phytobenthos of freshwater Thames II. The floristic composition and distribution of the smaller algae sample using artificial surfaces. Arch. Hydrobiol. 103(1): 83-97.

KING, D.K. CUMMINS, K.W. 1989. Autotrophic-heterotrophic community metabolism relationship of the woodland stream. Journal of Freshwater Ecology. 5: 205-218.

KRUPEK, R.A., BRANCO, C.C.Z. \& PERES, C.K. 2008a. Levantamento florístico das comunidades de macroalgas da bacia do rio das Pedras, região centro-sul do Estado do Paraná, Sul do Brasil. Hoehnea (São Paulo), v. 35, p. 25-44.

KRUPEK, R.A., BRANCO, C.C.Z. \& PERES, C.K. 2008b. Variação sazonal de alguns parâmetros físicos e químicos em três rios pertencentes a uma bacia de drenagem na região centro-sul do Estado do Paraná, Sul do Brasil. Acta Scientiarum. Biological Sciences, v. 30, p. 431-438.

KRUPEK, R.A., BRANCO, C.C.Z. \& PERES, C.K. 2007. Distribuição ecológica das comunidades de macroalgas da bacia de drenagem do Rio das Pedras, região Centro-Sul do estado do Paraná, sul do Brasil. Revista Brasileira de Botânica, v. 30, p. 173-182.

LAMPERT, W. \& SOMMER, U. Limnoecology: the ecology of lakes and streams. $2^{\mathrm{a}}$ edition. Oxford University Press. 2007. 
LANGDON, C. 1988. On the causes of interspecific differences in the growthirradiance relationship for phytoplankton. II. A general review. Journal of Plankton Research. 10: 1291-1312.

LEE, R.E. 2008. Phycology. 4 ed. Cambridge University Press, New York.

LELAND, H.V. \& CARTER, J.L. 1985. Effects of cooper on production of periphyton, nitrogen fixation and processing of littler in a Sierra Nevada, California, stream. Freshwater Biology 15:155-173.

LEUKART, P. 1995. Studies on the macroalgal vegetation of small soft-water stream in the Spessart mountains, Germany, with reference to algal distribution and seasonality. Archiv für Hydrobiologie: Algological Studies, Stuttgart. 79: 7792.

LEUKART, P. \& HANELT.D. 1995. Light requirements for photosynthesis and growth in several macroalgae from a small soft-water stream in the Spessart Mountains, Germany. Phycologia. 34: 528-532.

LEWIS, W.M.Jr., 1978. Analysis of succession in a tropical phytoplankton communit and new measure of succession rate. Amer.Natur. 112, 401- 414.

LIAW, W.K. \& MacCRIMMON, H. 1978. Assessing changes in biomass of river bed periphyton. Internationale Revue der Gesamtem Hydrobiologie und Hydrographie 63:155-171.

LOBO E.A., BUSELATO-TONIOLLI T.C. 1985. Tempo de exposição de um substrato artificial para o estabelecimento da comunidade de perifíton no curso inferior do rio Caí, Rio Grande do Sul, Brasil. Rickia 12:35-51.

LOBO E.A., CALLEGARO V.L.M., HRMANY G., BES D., WETZEL C.A. OLIVEIRA M.A. 2004. Use of epilithic diatoms as bioindicators from lotic systems in southern Brazil, with special emphasis on eutrophycation. Acta Limnologica Brasiliensia 16:25-40.

LYFORD, J.H. \& GREGORY, S.V. 1975. The dynamics and structure of periphyton communities in three Cascade Moutain streams. Verh. Internat. Verein. Limnol. 19: 1610-1616.

MAITLAND, P.S. Biology of Freshwaters. Glasgow: Blackie, 1978. 244p.

MARSAC, N.T. 1977. Ocurrence and nature of chromatic adaptation in Cyanobacteria. Journal of Bacteriology. 130: 82-91.

MARKER, A.F.H. NUSCH, H., RAI, H. \& RIEMANN, B. 1980. The measurement of photosynthetic pigments infreshwaters and standardization of methods: conclusion and recommendations. Arch. Hydrobiol. Beih., 14: 91-106. 
McINTIRE, C.D., \& PHINNEY, H.K. 1965. Laboratory studies of periphyton production and community metabolism in lotic environments. Ecol. Monogr. 35: 237-258.

MENDES, R.S., BARBOSA, F.A.R. 2002. Efeito de enriquecimento in situ sobre a biomassa da comunidade perifítica de um córrego de altitude da Serra do Cipó (MG). Acta Limnologica Brasiliensia 14: 77-86.

NECCH, O.Jr., PASCOALOTO, D. 1993. Seasonal dynamics of macroalgal communities in the Preto River basin, Sao Paulo, southeastern Brazil. Archiv fur Hydrobiologie, Stuttgart 129: 231-252.

NECCHI, O.Jr., PASCOALOTO, D., BRANCO, L.H.Z. 1994. Distribution of macroalgae in a tropical river basin from southeastern Brazil. Arch. Hydrobiol. 129: 459-471.

NECCHI, O.Jr., BRANCO, C.C.Z. ; SIMÕES, R.C.G. ; BRANCO, L.H.Z. 1995. Distribution of stream macroalgae in northwest region of São Paulo State, southeastern Brazil.. Hidrobiologia, Dordercht. 299: 219-230.

NECCHI, O.Jr.; ZUCCHI, M.R. 2001. Photosynthetic performance of freshwater Rhodophyta in response to temperature, irradiance, $\mathrm{pH}$ and diurnal rhythm.. Phycological Research. 49:.305-318.

NECCHI, O.Jr., BRANCO, L.H.Z., BRANCO, C.C.Z. 2003. Ecological distribution of stream macroalgal communities from a drainage basin in the Serra da Cananstra National Park, Minas Gerais, southeastern Brazil. Braz. J.of Biol. 63: 635-646.

$\mathrm{NECCHI}$, O.Jr. Light-related photosynthetic characteristics of lotic macroalgae. Hydrobiologia. 525: 139-155.

NECCHI, O.Jr., BRANCO, L.H.Z., SPEZAMIGLIO, D.N. 2008. Distribuição ecológica das comunidades de macroalgas de ambientes lóticos do Parque Nacional de Itatiaia (RJ, MG), Brasil.. Revista Brasileira de Botânica. 31: 135145.

ODUM, E.P. 1988. Ecologia. Guanabara, Rio de Janeiro, 434 pp.

OLIVEIRA, M.A., TORGAN, L.C., RODRIGUES, S.C. 2002. Diatoméceas perifíticas dos Arroios Sampaio e Sampainho, Rio Grande do Sul, Brasil. Acta Botânica Brasílica 16:1-12.

PANITZ, C.M.N. 1980. Estudo comparativo de diferentes substratos artificiais na represa do Lobo ("Broa"), São Carlos, SP. 224p. Dissertação (Mestrado em ecologia e recursos naturais - Limnologia), UFSCar, São Carlos, SP. 
PFANNSCHIMIDT, T. 2005. Acclimation to varying light qualities: toward the functional relationship of state transitions and adjustment of photosystem stoichiometry. Journal of Phycology. 41: 723-725.

PFISTER, P. 1993. Seasonality of macroalgal distribution pattern whitin the reach of a gravel stream (Isar, Tyrol, Austria). Arch. Hydrobiol. 129, 89-107.

PREZELIN, B.M.T. TILZER, O., SCHOFIELD, \& HAESE, C. 1991. The control of the production process of phytoplankton by the physical structure of the aquatic environment with special reference to its optical properties. Aquatic Sciences 53:136-186.

REYNOLDS, C.S., CARLING, P.A., \& BEVEN, K.J. 1991. Flow in river channels: new insights into hydraulic retention. Arch. Hydrobiol., 121: 171-179.

RICHARDSON, K., BEARDALL, J., RAVEN, J.A. 1983. Adaptation of unicellular algae to irradiance: An analysis of strategies. New Phytologist 93:157-191.

RICO-GARCÍA, E., HERNÁNDEZ-HERNÁNDEZ, F., SOTO-ZARAZÚA, G.M. \& HERRERA-RUIZ, G. 2009. Two new Methods for the Estimation of Leaf Area using Digital Photography. International Journal of Agriculture and Biology. 11(4): 397-400.

RIER, S.T., STEVENSON, J. \& LALIBERTE, G.D. 2006 Photo-acclimation response of benthic stream algae across experimentally manipulated light gradients: a comparison of growth rates and net primary productivity. Journal of Phycology. 42: 560-567.

RIVKIN, R.B. 1989. Influence of irradiance and spectral quality on the carbon metabolism of fitoplankton. I. Photosynthesis, chemical compositiom and growth. Marine Ecology Progress Series 55:291-304.

ROBERTS, S. SABATER, S. \& BEARDALL, J. 2004. Benthic microalgal colonization in stream of differing riparian cover and light availability. Journal of Phycology. 40: 1004-1021.

ROUND, F.E. 1964. The ecology of benthic algae. In: Jackson, D.F. (ed.). New York Pelnum. P. 138-184.

ROUND, F.E. 1965. The epipsammon. A relatively unknown freshwater algal association. Br. Phycol. Bull., 2(6): 456-462.

ROUND, F.E. A Biologia das algas. Tradução de Francisco Perlingeiro Neto. 2.ed. Rio de Janeiro: Ed. Guanabara Dois, 263p, 1983. 
SARTORY, D.P. \& GROBBELAAR, J.U. 1984. Extraction of chlorophyll a from freshwater phytoplankton for spectrophotometric analysis. Hydrobiologia, 114: 177-187.

SCHWARZBOLD, A. 1990. Métodos ecológivos aplicados ao estudo do perifíton. Acta Limnologica Brasiliensia. 3: 545-592.

SCHWARZBOLD, A., ESTEVES, F.A. \& PANOSSO, R.F. 1990. Relações entre peso seco e clorofila a do perifíton em função de diferentes idades e épocas de coletas de pecíolos de Eichhornia azurea Kunth. Acta. Limnol. Brasil., 3: 493515.

SHEATH, R.G. \& BURKHOLDER, J.M. 1985. Characteristics of softwater streams in Rhode Island II. Composition and seasonal dynamics of macroalgal communities. Hidrobiologia 28:109-118.

SHEATH, R.G., HAMILTON, P.B., HAMBROOK, J.A., COLE, K.M. 1989. Stream macroalgae of eastern boreal forest region of North America. Can. J. Bot. 67, 3553-3562.

SHEATH, R.G. \& COLE, K.M. 1992. Biogography of stream magroalgal in North America. Journal of Phycology 28:448-460.

SHEATH, R.G. MORINSON, M.O. KORCH, J.E. KACZMAREZYK, D., COLE, K.M. 1986. Distribuition of stream macroalgae in south-central Alasca. Hydrobiologia, Dordrechtv. 135: 259-269.

SHERWOOD, A.R. \& SHEATH, R.G. 1999. Seasonality of macroalgae and epilithic diatoms in spring-fed streams in Texas, U.S.A. Hydrobiologia 390: 7382.

SHORTREED, K. S. \& STOCKNER, J.G. 1983. Periphyton biomass and species composition in a coastal rainforest stream in British Columbia: effects of environmental changes caused by logging. Canadian Journal of Fisheries and Aquatic Sciences. 40: 1887-1895.

SLÁDECKOVÁ, A. 1962. Limnological investigation methods for the periphyton ("Aufwuchs") community. Bot. Rev., 28(2): 286-350.

STOCK, M.S. \& WARD, A.K. 1991. Blue-greem algal mats in a small stream. J. Phycol. 27, 692-698.

SIMÃO, E., NAKAMURA, A.T. \& TAKAKI, M. 2008. Use of Insulfim ${ }^{\circledR}$ like plastic filter to simulate canopy filtered light for germination tests. Naturalia. 31: 28-33. 
SKINNER L. F., COUTINHO R. 2005. Effects of microhabitat distribution and substrate roughness on barnacle Tetraclita stalactifera (Lamarck, 1818) settlement. Brazilian Archives of Biology and Technology 48:1-8.

SLÁDEDKOWÁ, A. 1962. Limnological investigation methods for the periphyton ("aufwuchs") community. Botanical Review 28:236-350.

SLÁDEDKOWÁ, A. 1962. Limnological investigation methods for the periphyton ("aufwuchs") community. Botanical Review 28:236-350.

SOARES, J.J. 1981. Estudos sobre biomassa e produtividade do perifíton em macrófitas na Represa do Lobo, São Carlos - SP. Tese de Doutorado UFSCAR, 233p.

SOKAL, R.R. \& ROHLF, F.J. Biometry. New York: W. H. Freeman, 1981 p.

SOROKIN, C. \& KRAUSS, R. W. 1957. The effects of light intensity on the growth rates of green algae. Public Health Service Special Research Fellow of the National Microbiological Institute. 109-113.

STEINMAN, A.D., McINTIRE, GREGORY, S.V.L., LAMBERTI, G.A. Effects of irradiance and grazing on lotic algal assemblages. Journal of Phycology. 25, 478-485, 1989.

STEINMAN, A.D. \& McINTIRE, C.D. 1987. Effects of irradiance on the community structure and biomass of algal assemblages in laboratory streams. Canadian Journal of Fisheries and Aquatic Sciences. Ottawa. 44: 1640-1648.

STEVENSON, R.J., BOTHWELL, M.L., LOWE, R.L. (eds): Algal ecology freshwater benthic ecosystems. - Academic Press, San Diego. p.150-181, 1996.

TANDEAU de MARSAC, N. 1983. Phycobilisomes and complementary chromatic adaptation in cyanobacteria. Bull. Inst. Pasteur 81:201-254.

THOMAZ, E.L. \& VESTENA, L.R. 2003. Aspectos Climáticos de GuarapuavaPR. Guarapuava: Editora UNICENTRO. 106 p.

TRUNDEAU, V. \& RASMUSSEN, J.B. 2003. The effect of water velocity on stable carbon and nitrogen isotope signatures of periphyton. Limnology and Oceanography. 48: 2194-2199.

VANNOTE, R.C., MINSHALL, G.W. CUMMINS, SEDELL, J.R. \& CUSHING, C.E. 1980. The river continuum concept. Canadian Journal of Fisheries and Aquatic Sciences. 37: 130-137.

VOGELMAN, T.C., \& SCHEIBE, J. 1978. Action spectrum for chromatic adaptation in the blue-green alga Fremyella diplosiphon. Planta 143:233-239. 
WALLEN, D.G. 1970. The effect of light quality on growth rates, photosynthetic rates and metabolism in plankton algae. Dissertation os Simon Fraser University.

WARD, J.V. 1989. The four-dimensional nature of lotic ecosystems. Journal of North American Benthologycal Society. 8: 02- 08.

WETZEL, R.G. Limnologia. Barcelona, Omega, 1981. 679 p.

WETZEL, R.G. 1983. Periphyton of freshwater ecosystems developments. The Hague. Dr. W. Junk publishers. 364p. (Hydrobiology 17).

WETZEL, R.G. 1965. Techniques and problems of primary productivity measurements in higher aquatic plants and periphyton. Memorie dell Instituto italiano de hidrobiologia. Dott. Marco de machi 18: 240-267.

WHITFORD, L.A. 1960. Ecological distribution of freshwater algae. In: TRYON, C.A. Jr. \& HARTMAN, R.T. (ed.) Ecology of algae. Pymatuning Special Publications, 2. Ann Arbor: Edward Brothers Inc., p. 2-10.

WHITTON, B.A. Algae. In: WHITTON, B.A. (ed.). River ecology. Blackwell Scientific Publ., Oxford. 725 p. 1975. 
Apêndice

Figuras 


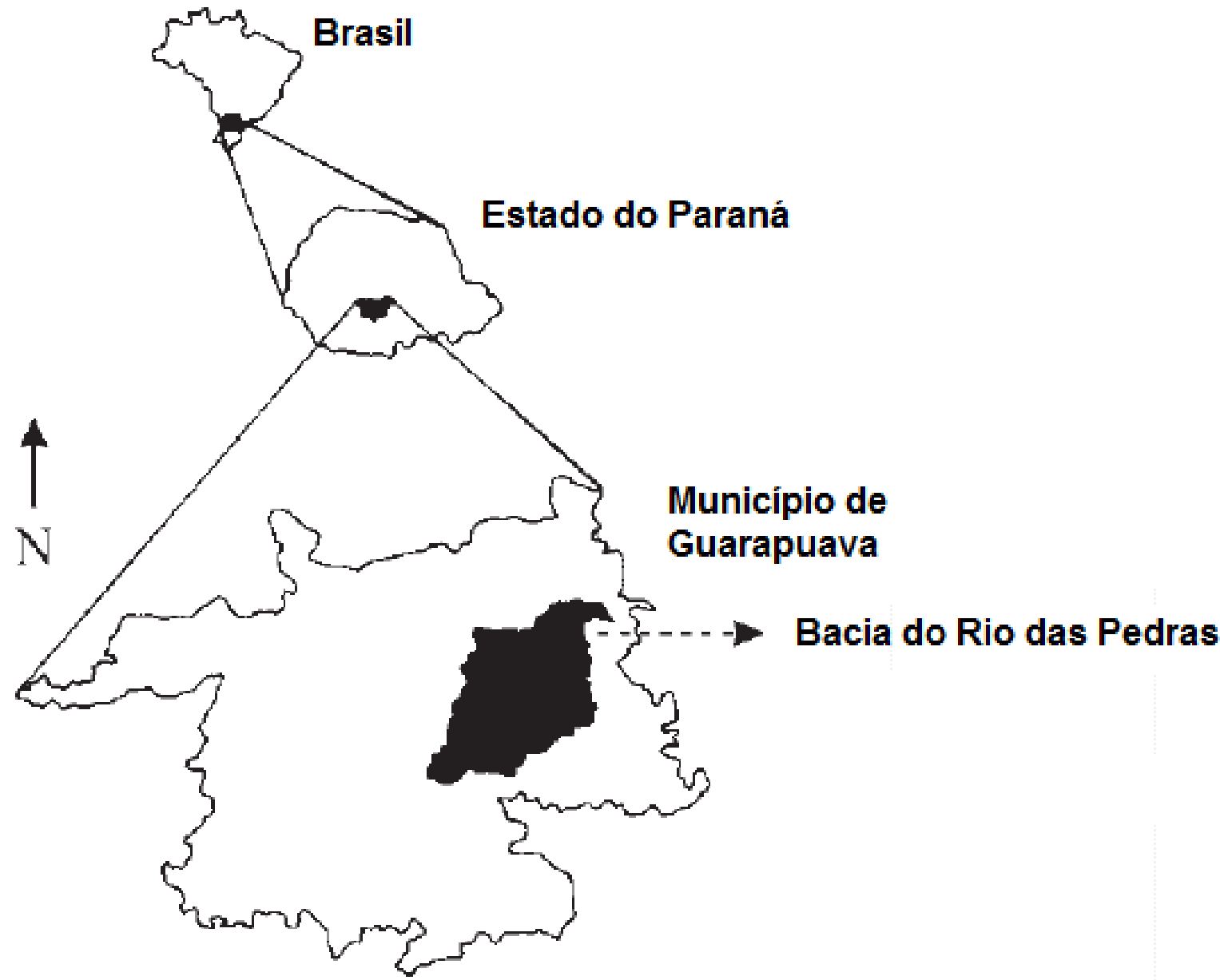

Figura 1. Localização da Bacia do Rio das Pedras na região Centro-Sul do Estado do Paraná, Sul do Brasil. 

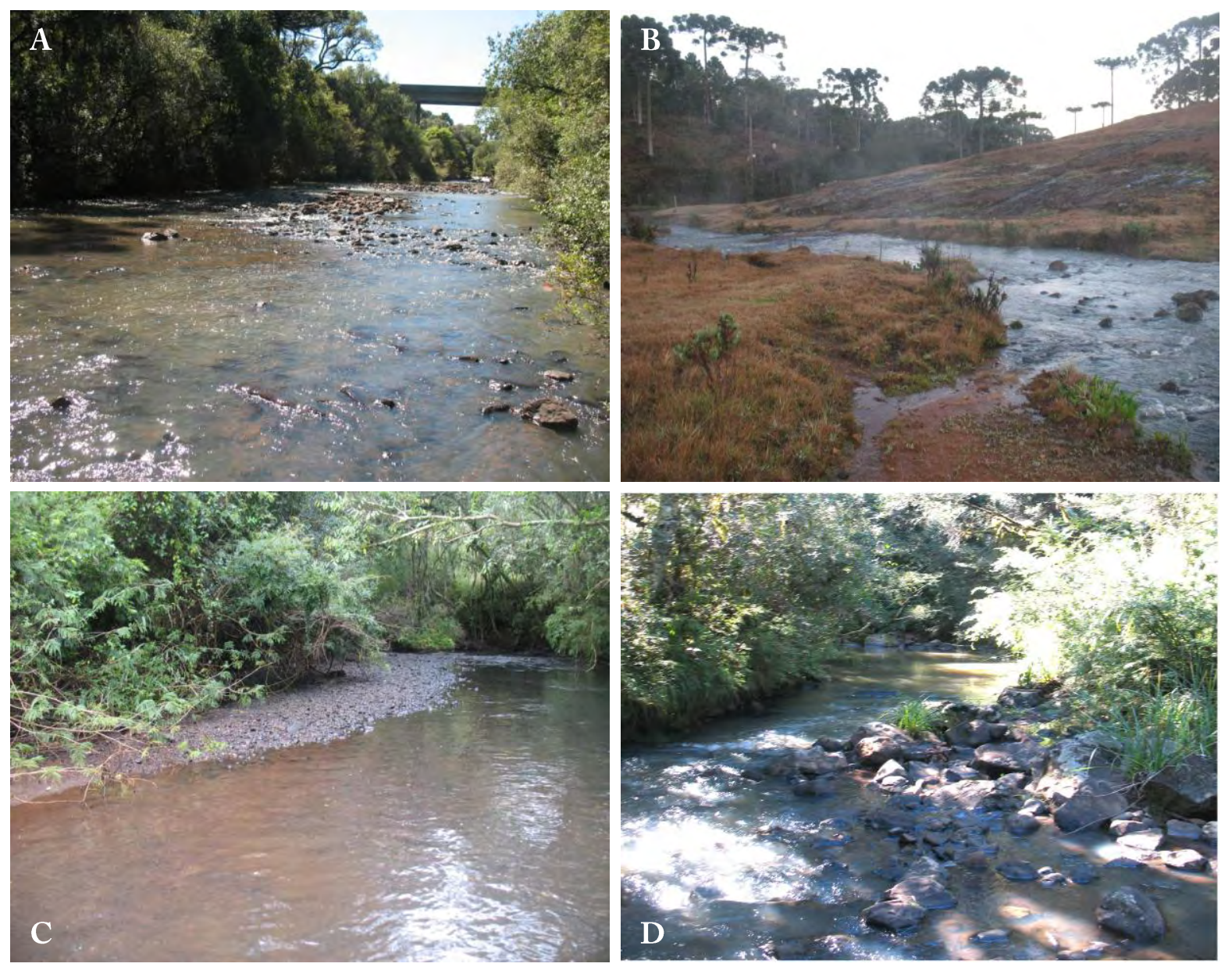

Figura 2. A. Rio das Pedras; B. Rio Lajeado; C. Rio Mortes; D. Rio Guabiroba. 
A
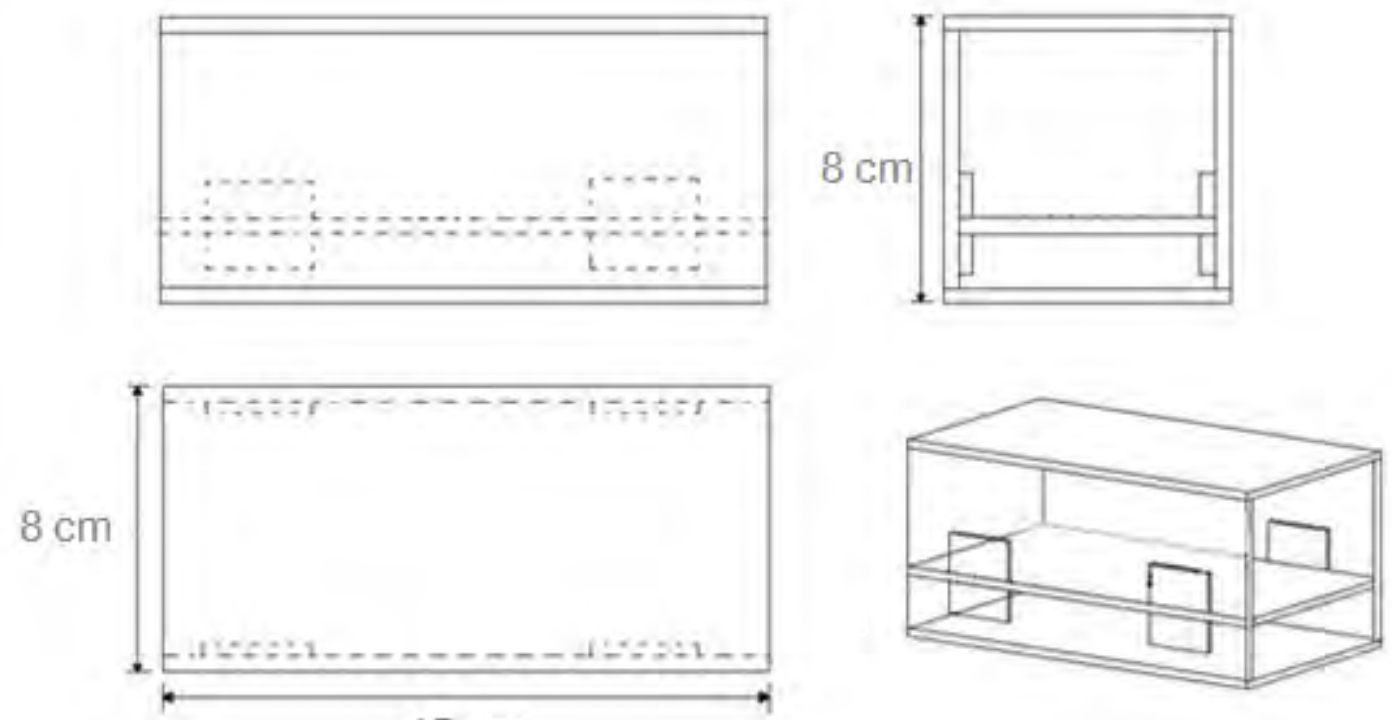

$15 \mathrm{~cm}$

B

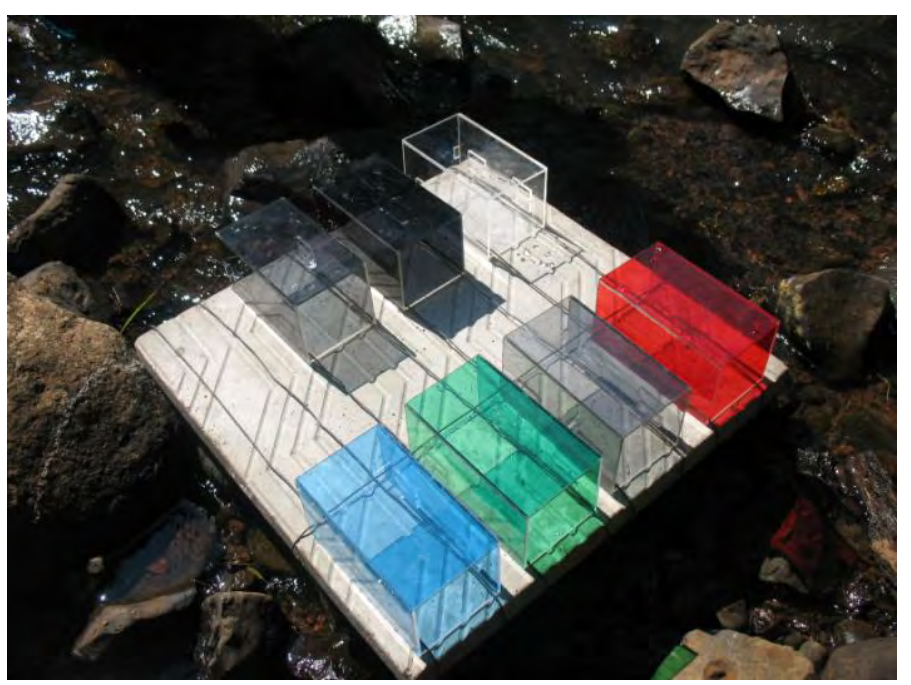

Figura 3. Amostrador artificial. (A) Desenho esquemático dos amostradores artificiais utilizados no experimento. (B) Fotografia dos amostradores de cada tratamento acoplados ao bloco de concreto. 

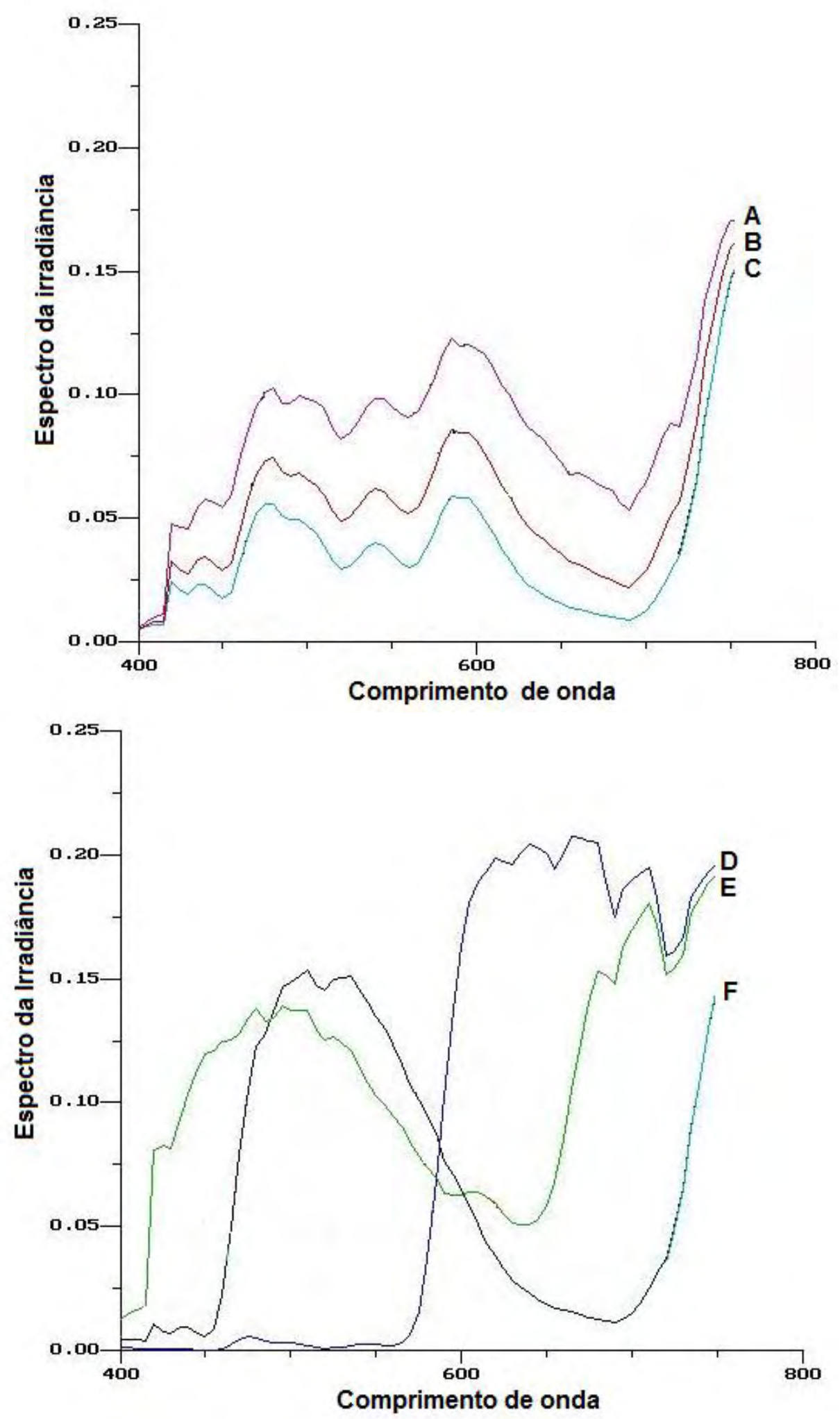

Figura 4. Composição espectral dos tratamentos criados no experimento. (1) A- $50 \%$ de atenuação, B- $70 \%$ de atenuação e C- $90 \%$ de atenuação. (2) DLuz vermelha, E-Luz azul, F-Luz verde. 


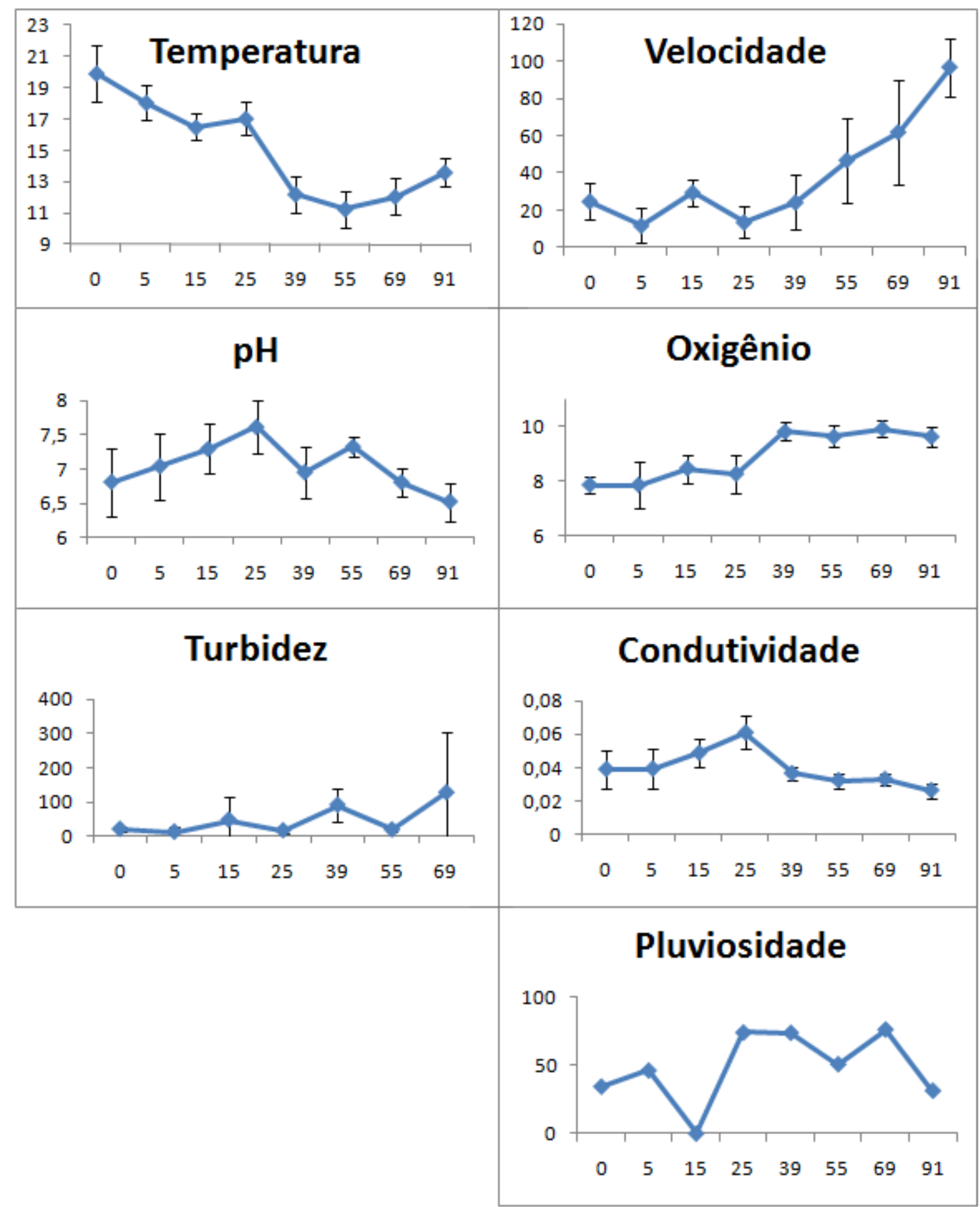

Figura 5. Variação das variáveis físico-químicas durante o período de experimento (91 dias). Temperatura $\left({ }^{\circ} \mathrm{C}\right)$, Velocidade da correnteza $\left(\mathrm{cm} \cdot \mathrm{s}^{-1}\right)$, $\mathrm{pH}$, Oxigênio Dissolvido (mg. $\left.\mathrm{L}^{-1}\right)$, Turbidez (UTN), Condutividade $\left(\mu \mathrm{Scm}^{-1}\right)$ e Pluviosidade acumulada $(\mathrm{mm})$. 


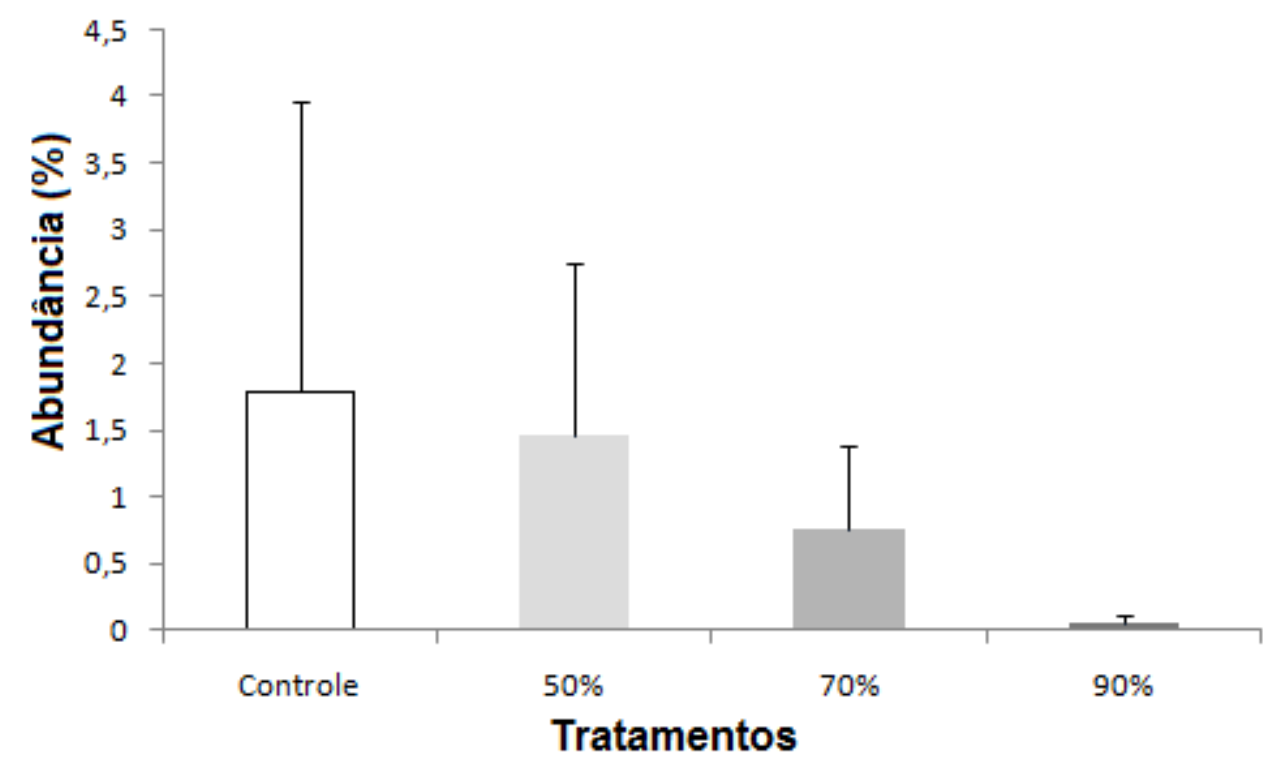

A

B

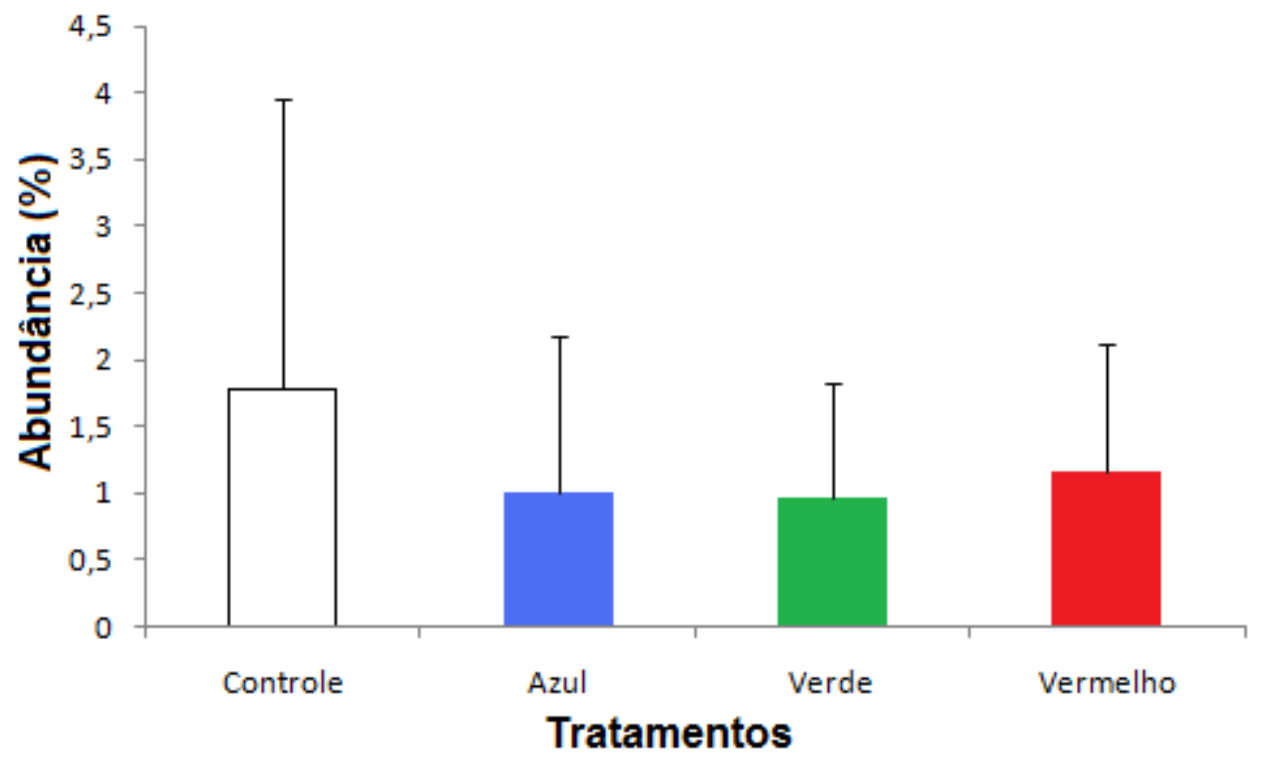

Figura 6. Valores médios de abundância global nos diferentes tratamentos de luz. (A) Valores médios de abundância nos tratamentos que envolveram a variação quantitativa da luz. (B) Valores médios de abundância nos tratamentos que envolveram a variação quantitativa da luz. 


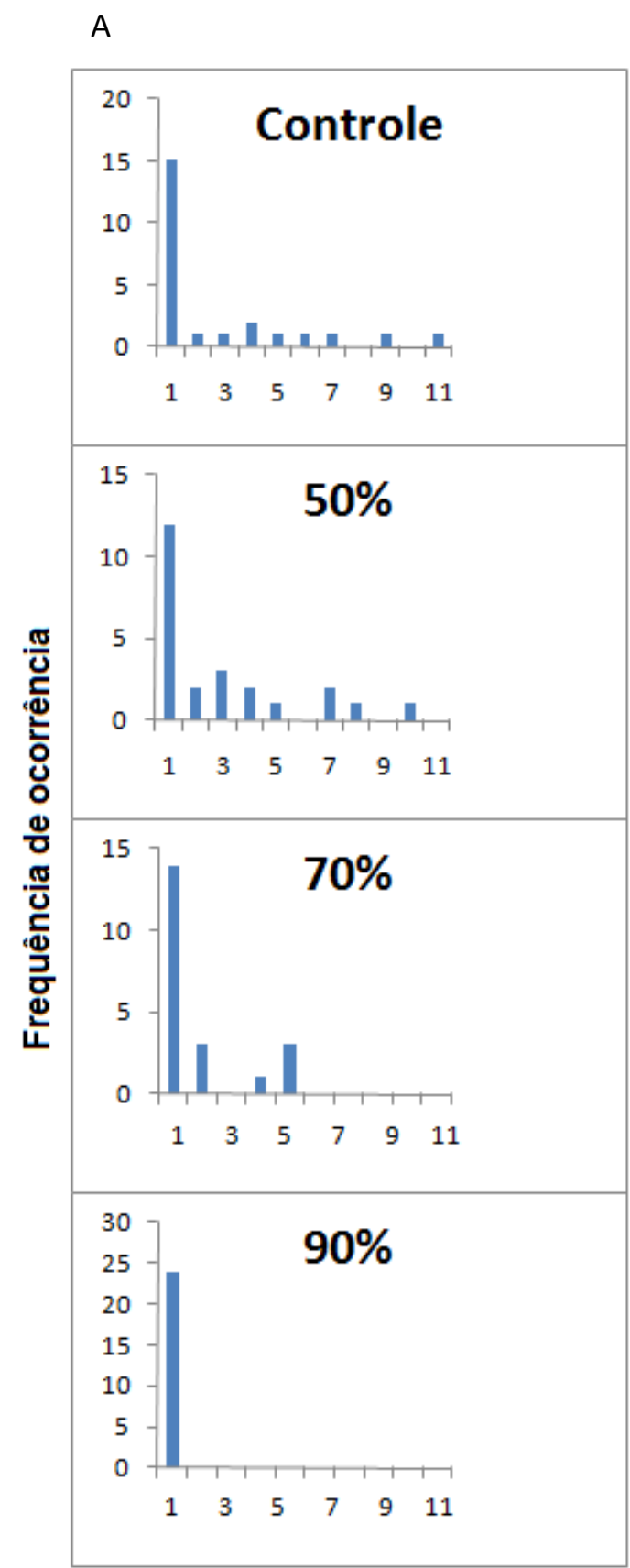

Abundância

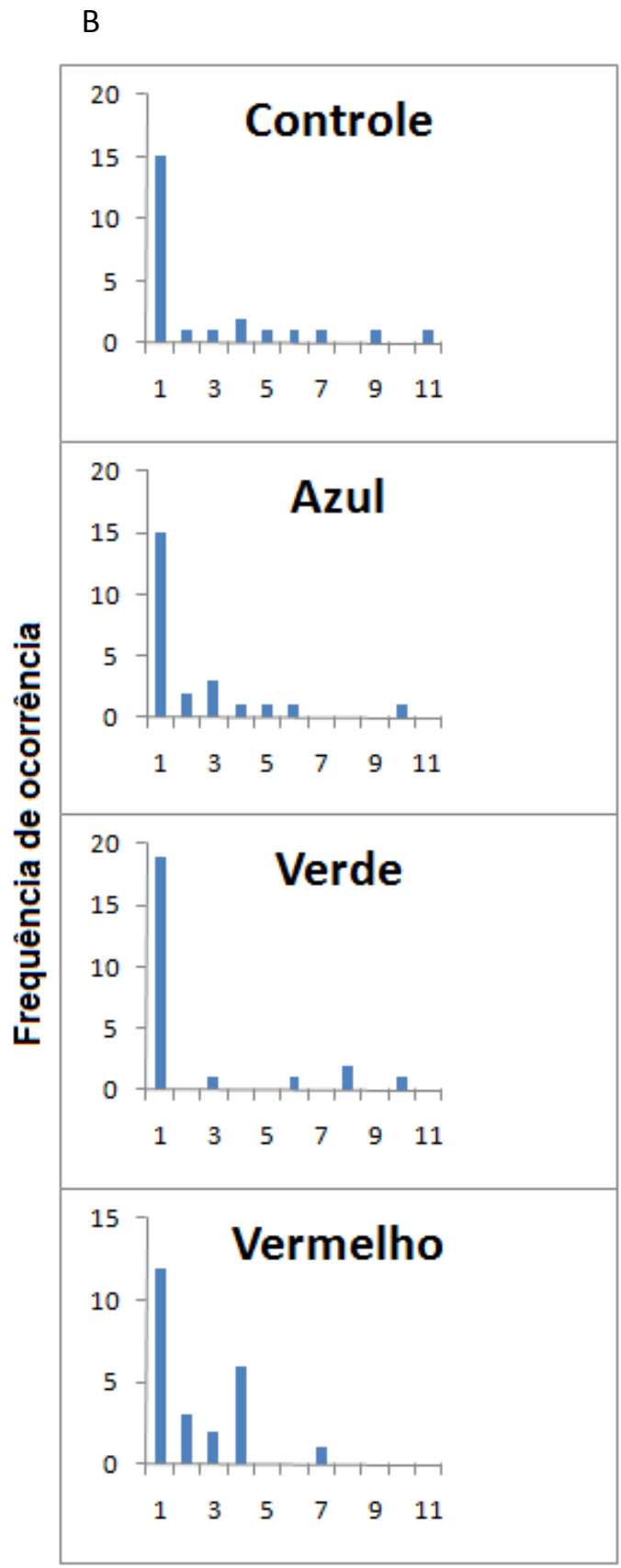

Abundância

Figura 7. Gráfico com a frequencia de ocorrencia dos valores de abundância nos tratamentos que diferiram a quantidade da irradiância $(A)$ e qualidade de irradiância (B). $1(0 \%-0,88 \%) ; 3(1,76 \%-2,74 \%) ; 5(3,53 \%-4,41 \%) ; 7(5,29 \%$ $-6,18 \%) ; 9(7,06 \%-7,94 \%) ; 11(>8,83 \%)$. 
A

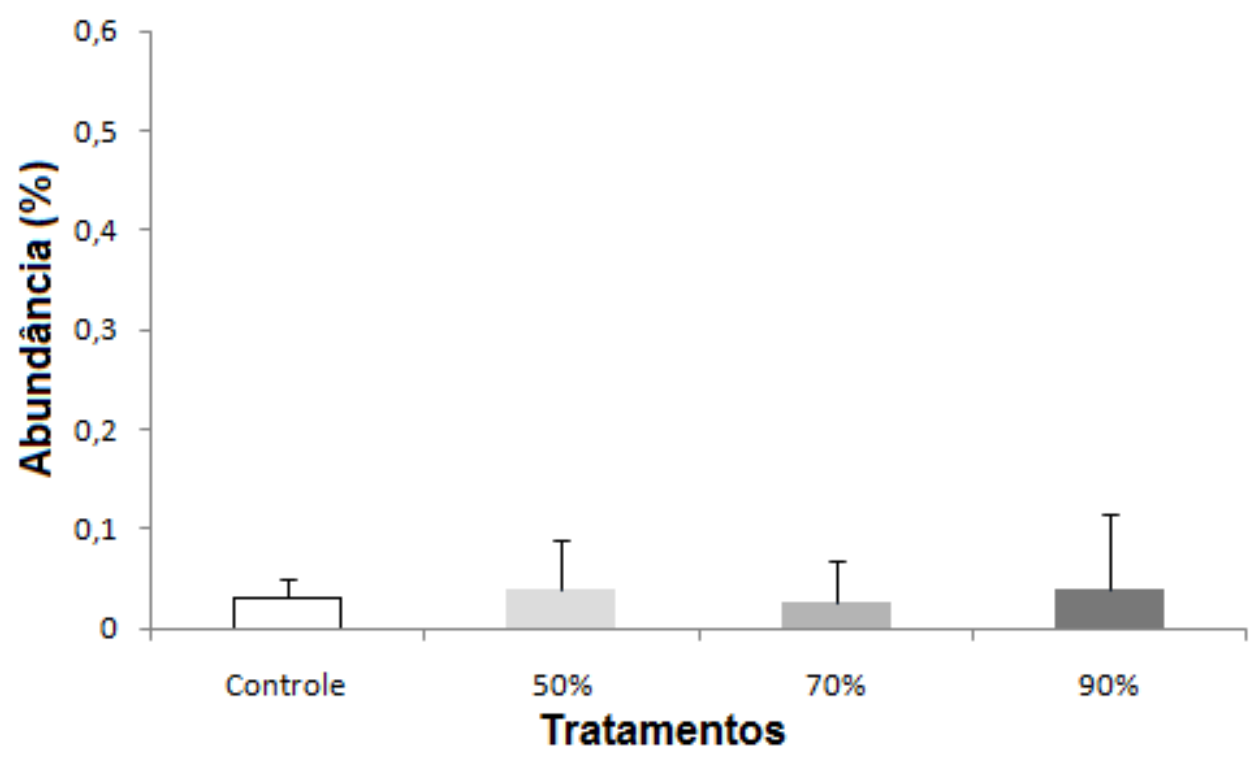

B

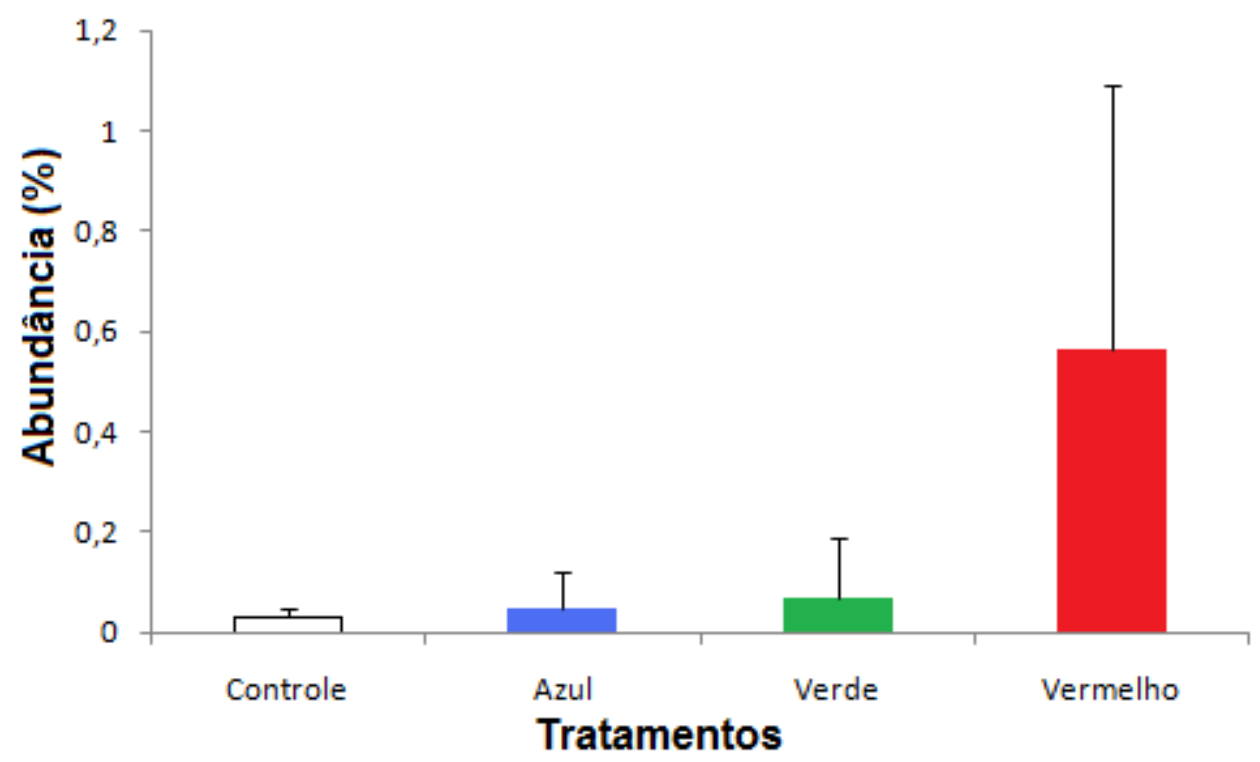

Figura 8. Valores médios de abundância da Divisão Cyanophyta nos diferentes tratamentos de luminosidade. (A) Tratamentos envolvendo a variação da quantidade da irradiância. (B) Tratamentos envolvendo a variação da qualidade da irradiância. 

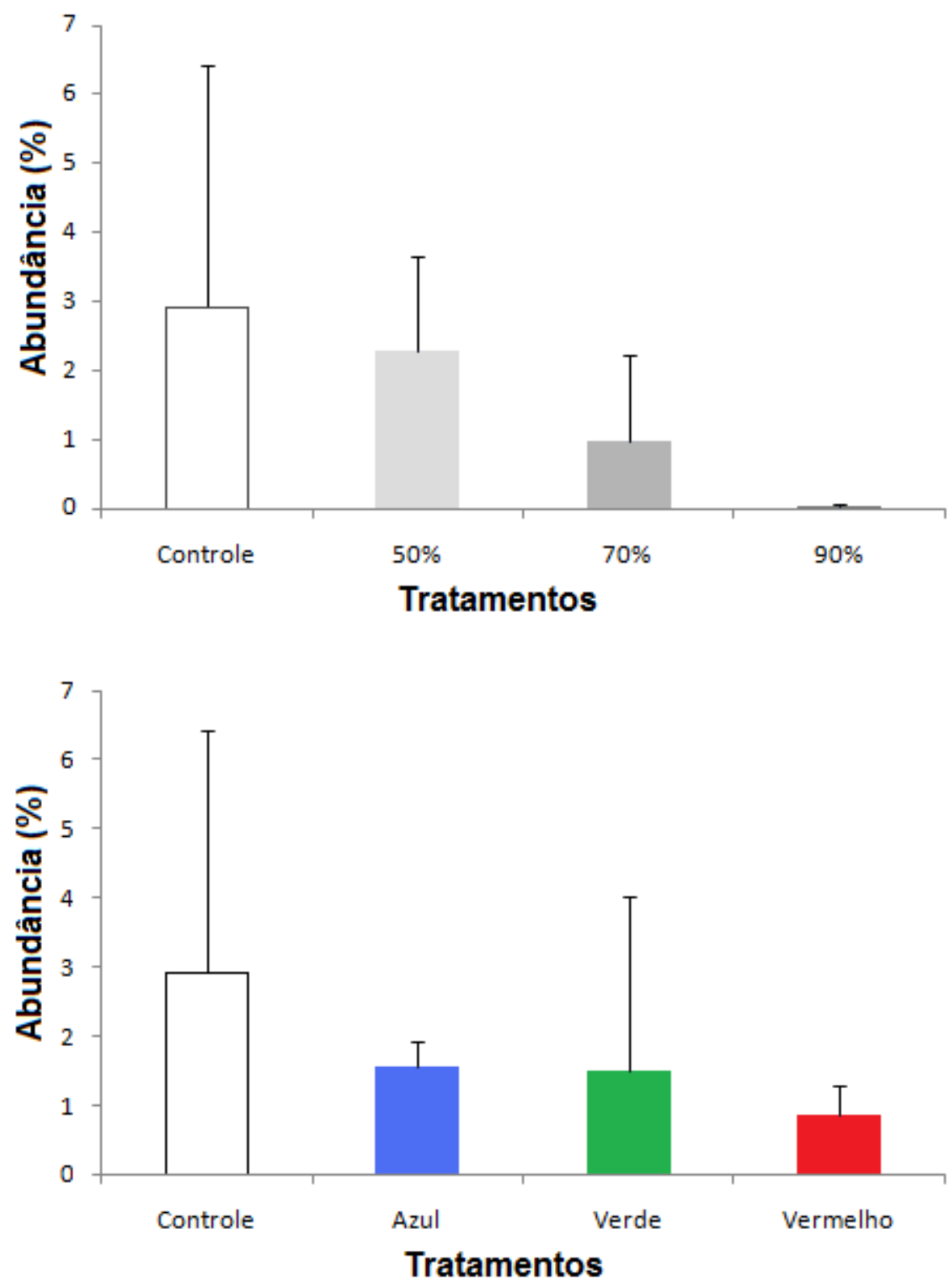

B

Figura 9. Valores médios de abundância da Divisão Chlorophyta nos tratamentos de luminosidade. (A) Tratamentos envolvendo a variação da quantidade da irradiância. (B) Tratamentos envolvendo a variação da qualidade da irradiância. 
A
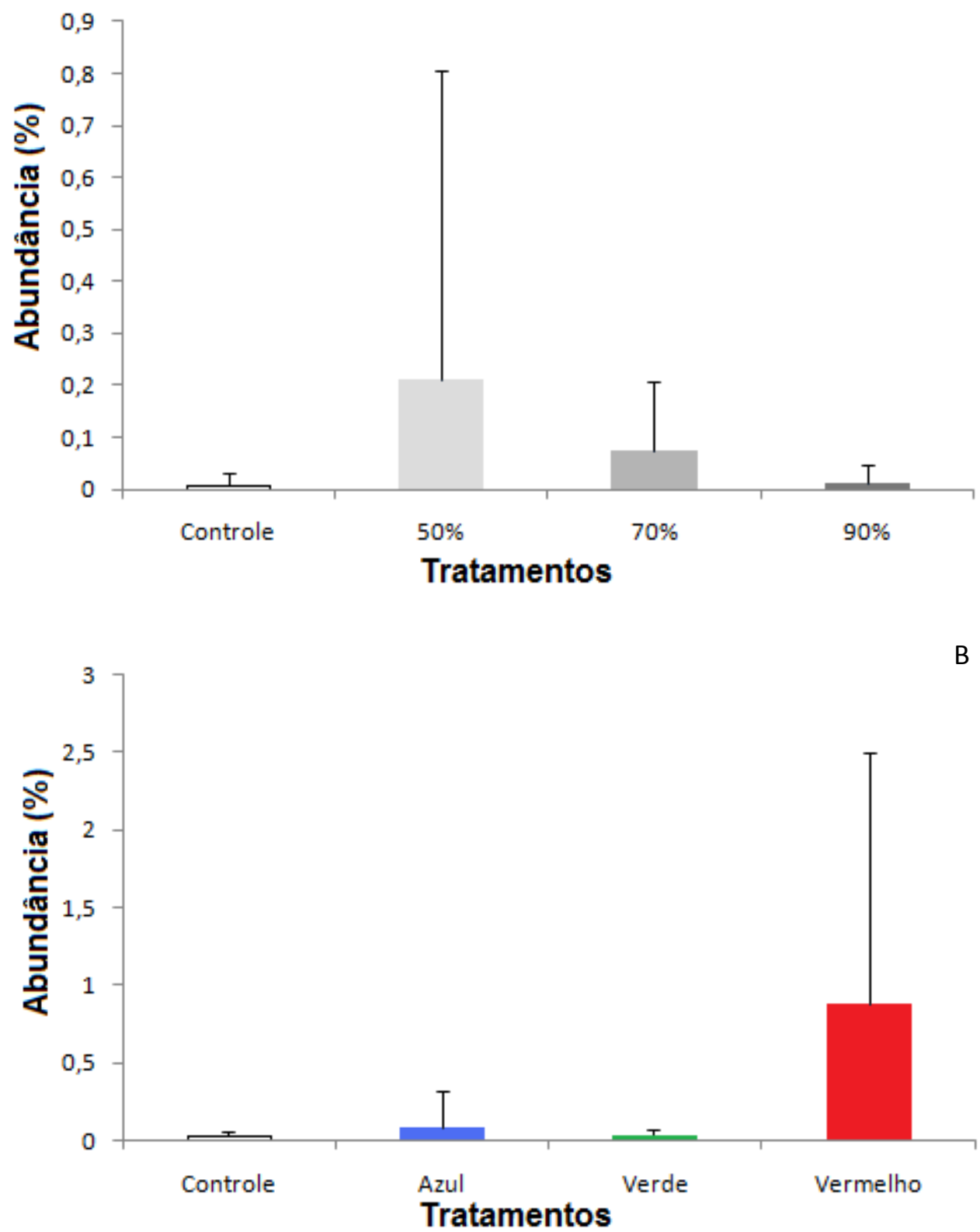

Figura 10. Valores médios de abundância da Divisão Rhodophyta nos tratamentos de luminosidade. (A) Tratamentos envolvendo a variação da quantidade da irradiância. (B) Tratamentos envolvendo a variação da qualidade da irradiância. 


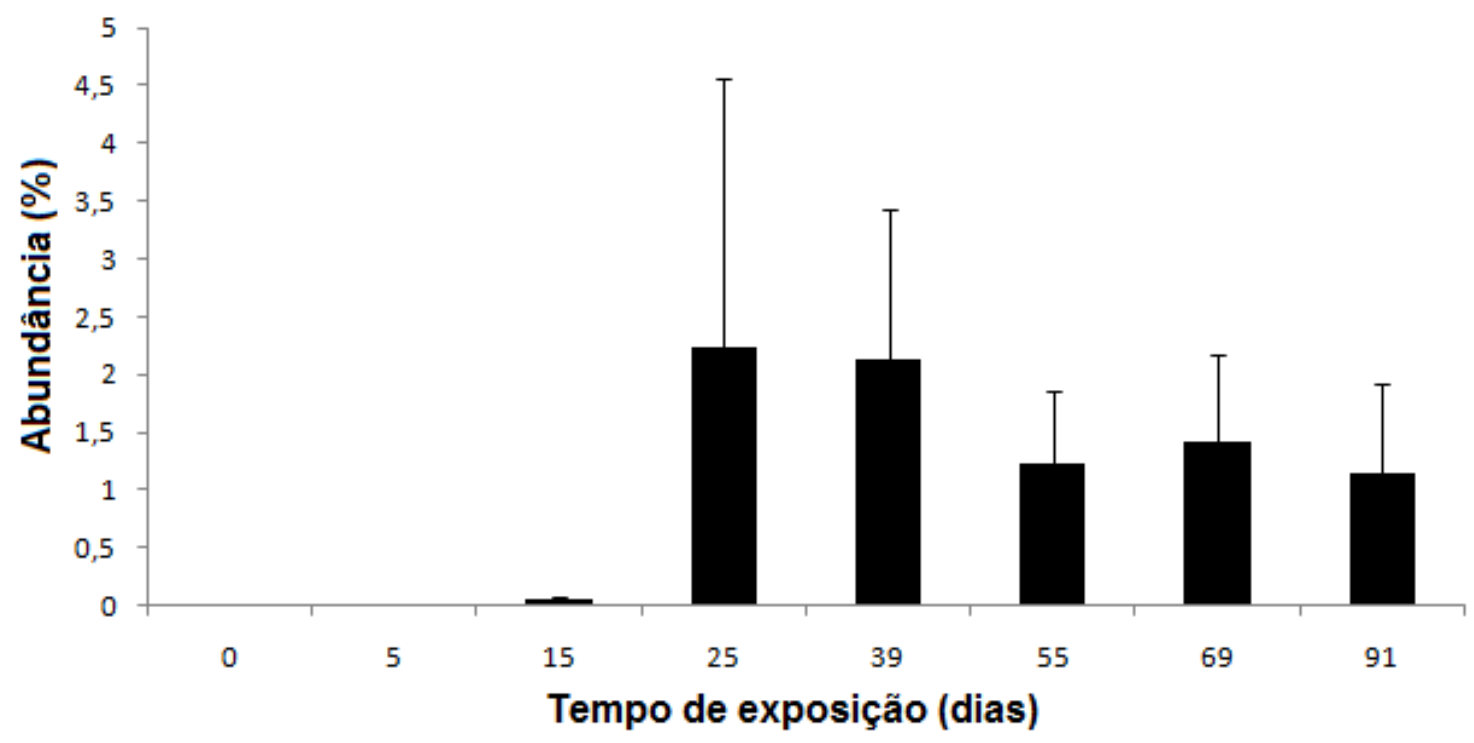

Figura 11. Variação dos valores de abundância global ao longo do tempo de experimentação. 


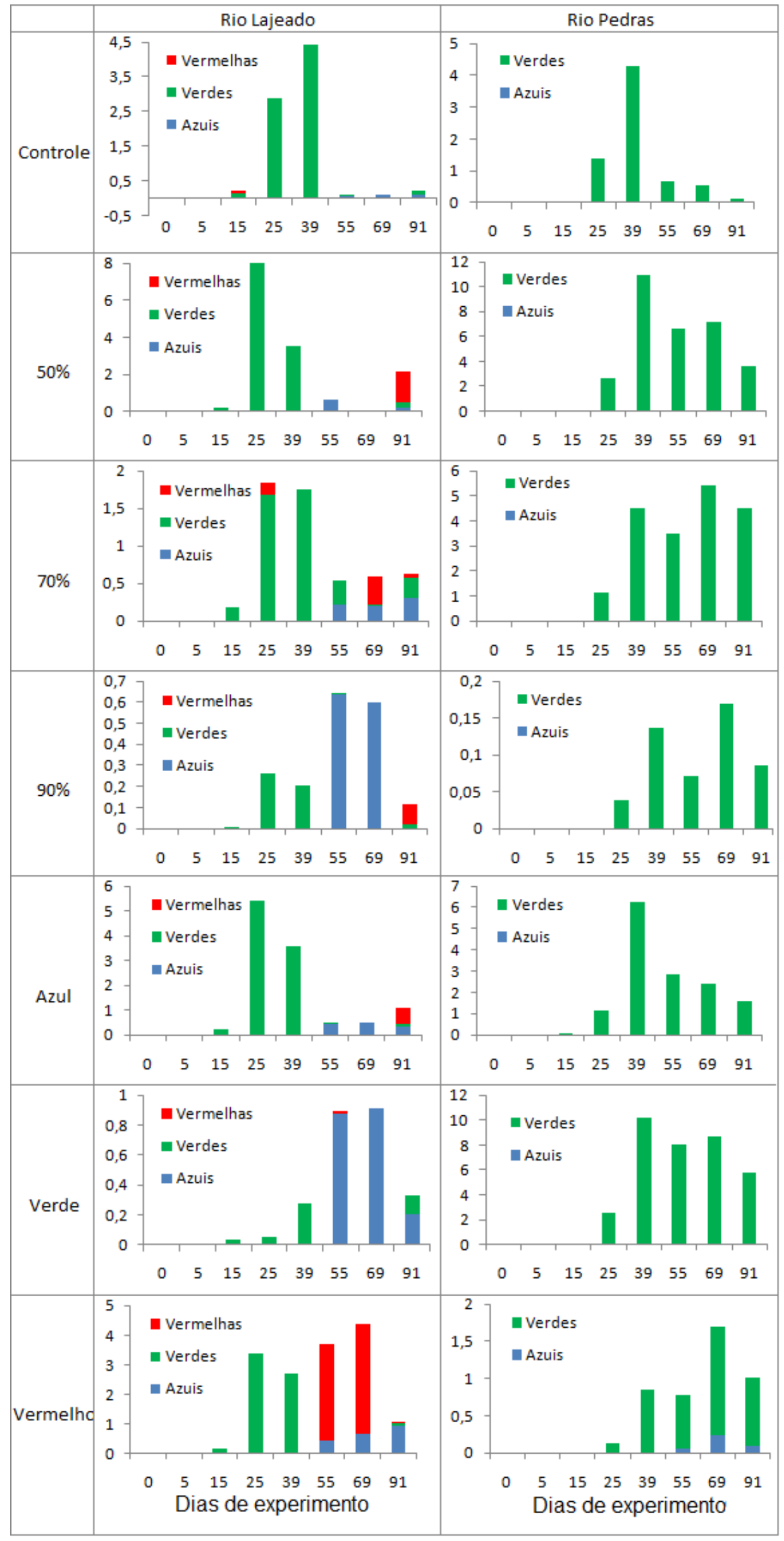

Figura 12. Contribuição dos táxons, para o Rio Lajeado e Pedras, ao longo do temp0 (91 dias) para cada tratamento quantitativo e qualitativo da luz 


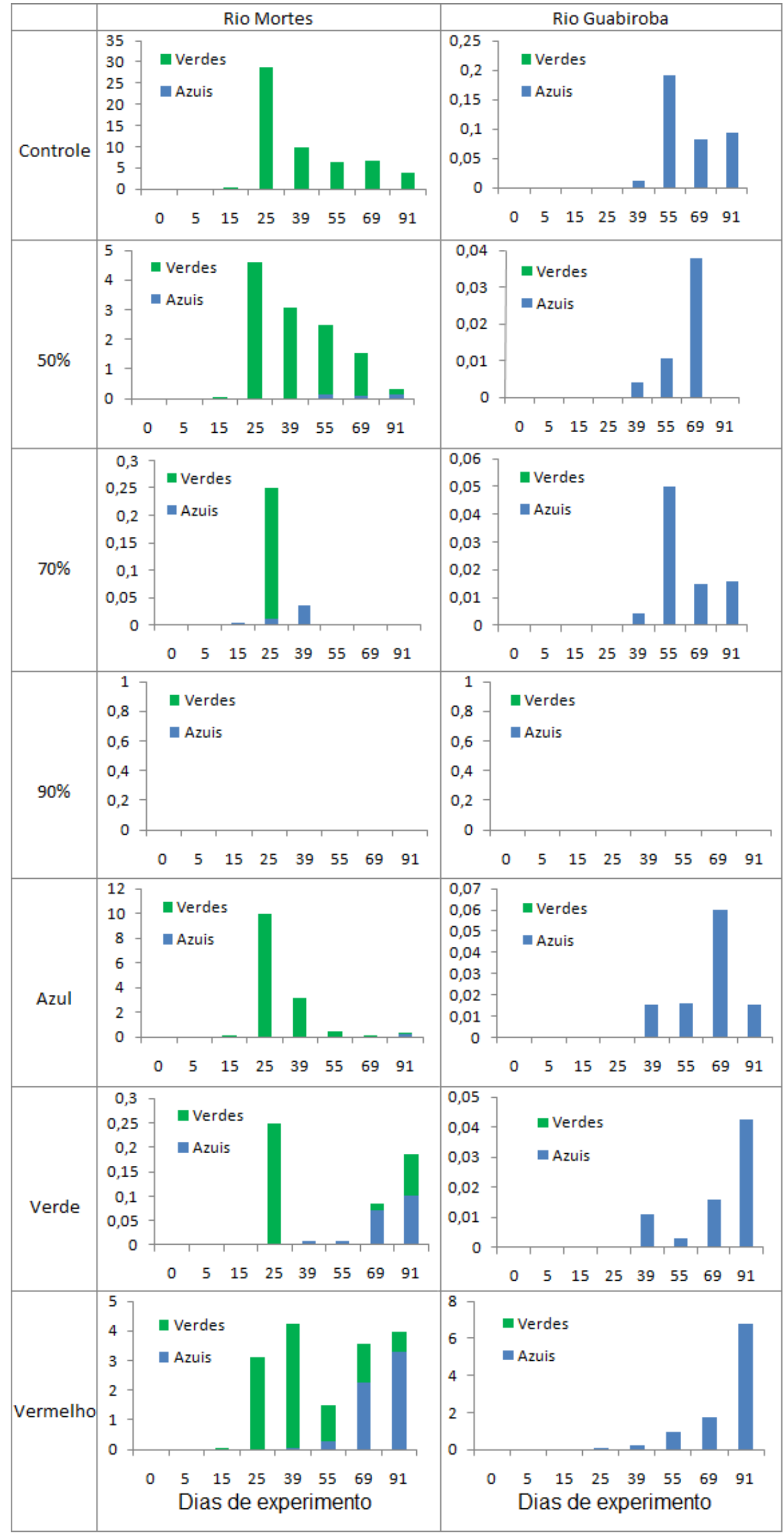


A

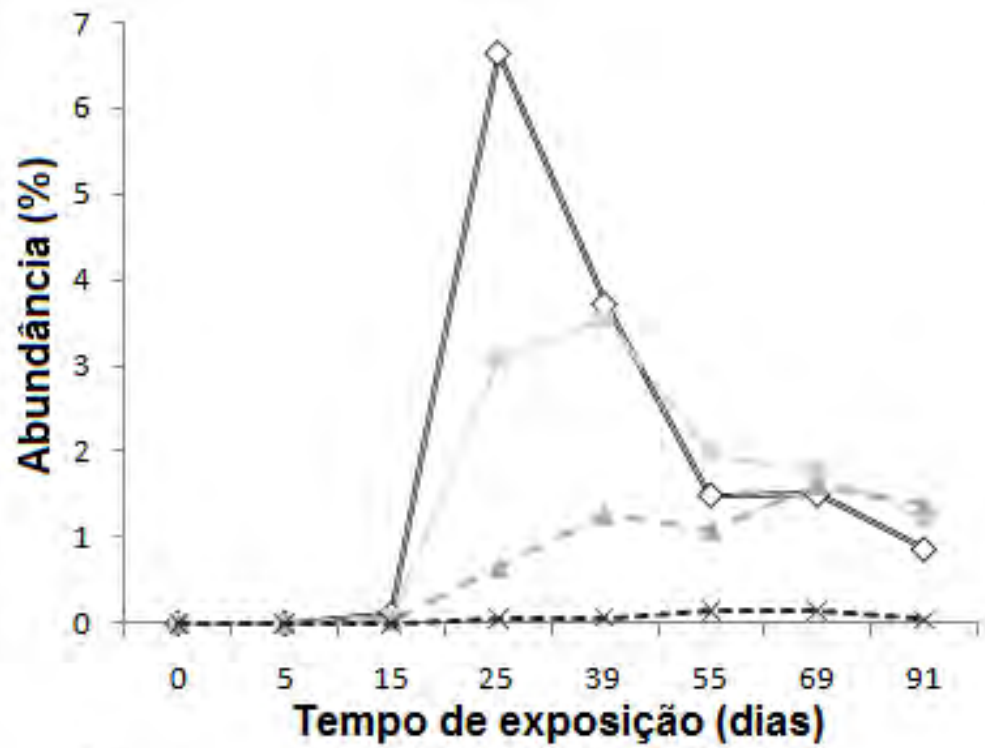

$\longrightarrow$ controle $50 \%$

$-x-70 \%$

$---3-.90 \%$

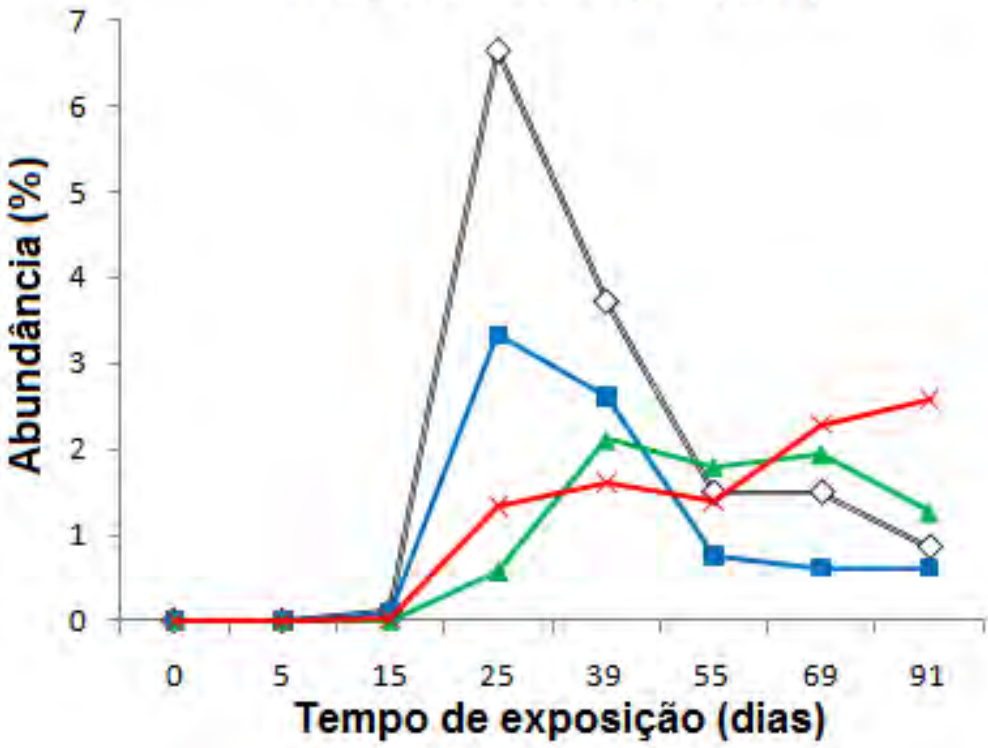

B

$\leadsto$ Controle

- -Azul

- Verde

$\because$ Vermelho

Figura 14. Variação dos valores de abundância global nos diferentes tratamentos de luminosidade ao longo do tempo. (A) Variação da abundância nos tratamentos que envolveram a variação da quantidade da irradância. (B) Variação dos valores de abundância nos tratamentos que envolveram a variação da qualidade da irradância. 

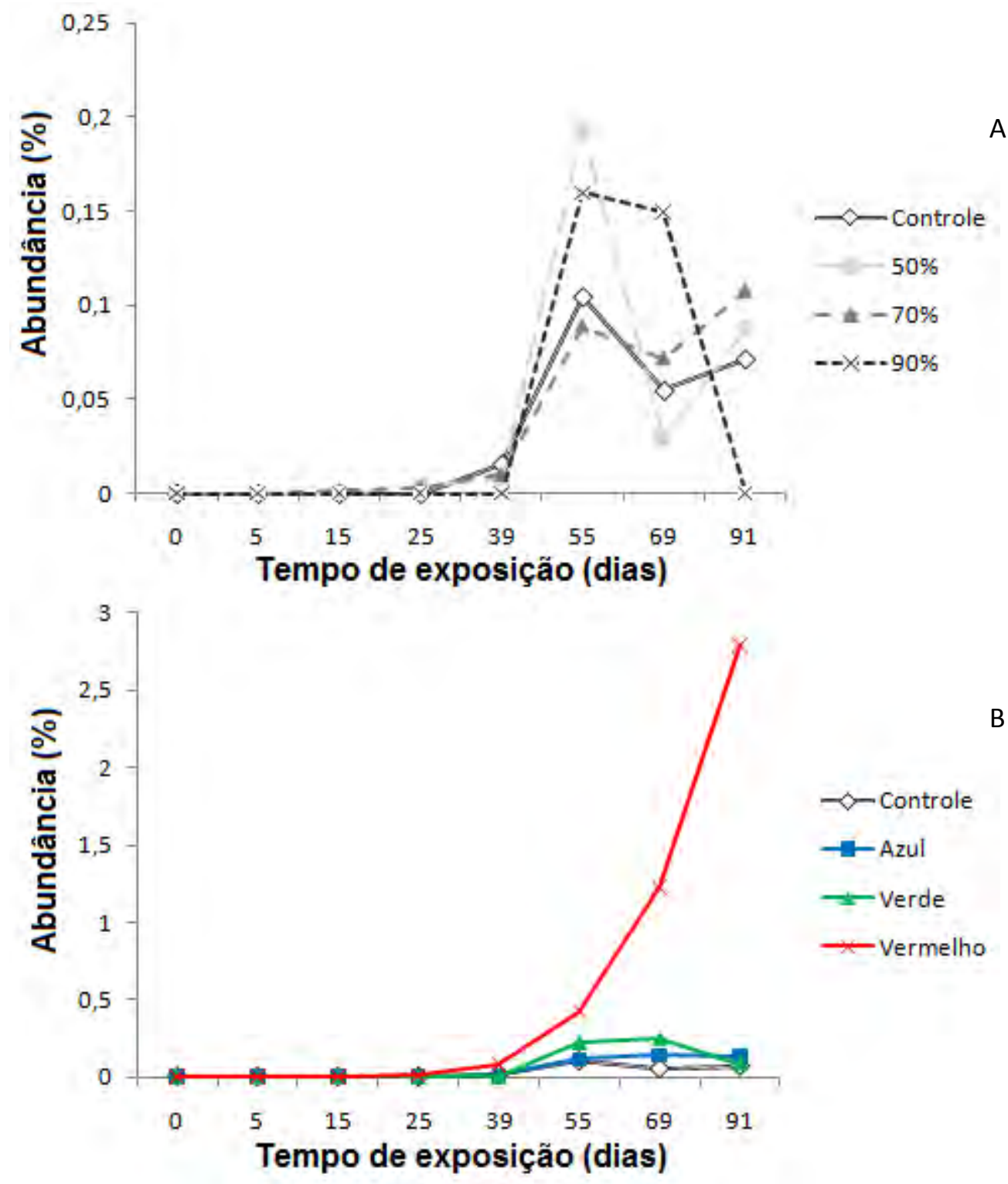

Figura 15. Variação dos valores de abundância da Divisão Cyanophyta ao longo do tempo (91 dias) diante dos tratamentos de luminosidade. (A) Tratamentos envolvendo a variação da quantidade da irradiância. (B) Tratamentos envolvendo a variação da qualidade da irradiância. 


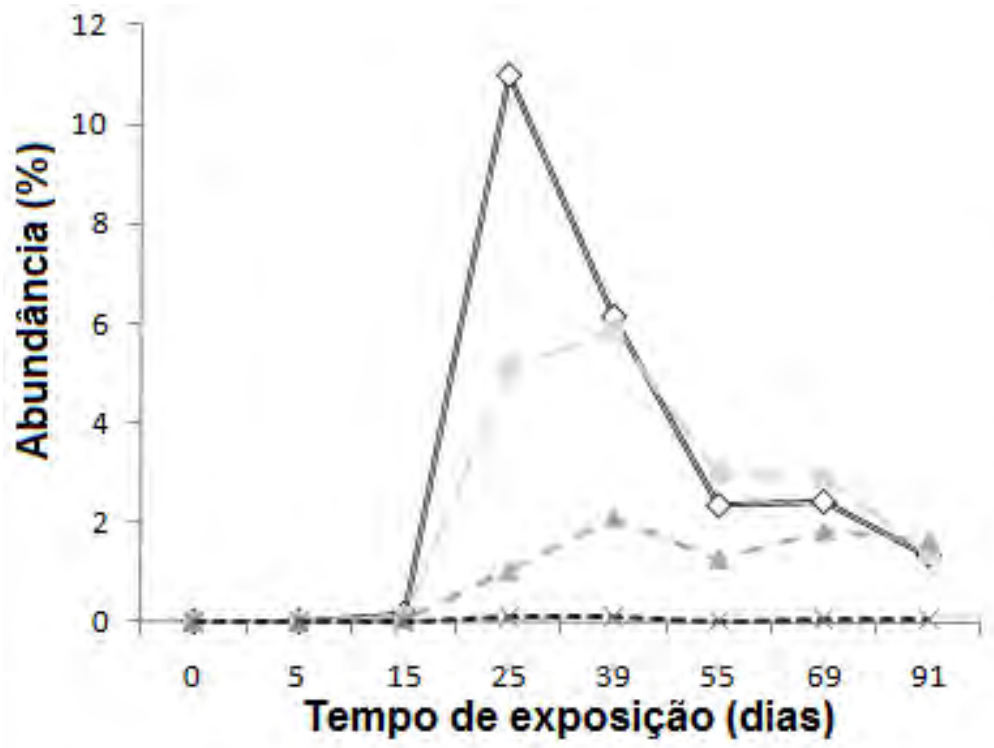

A
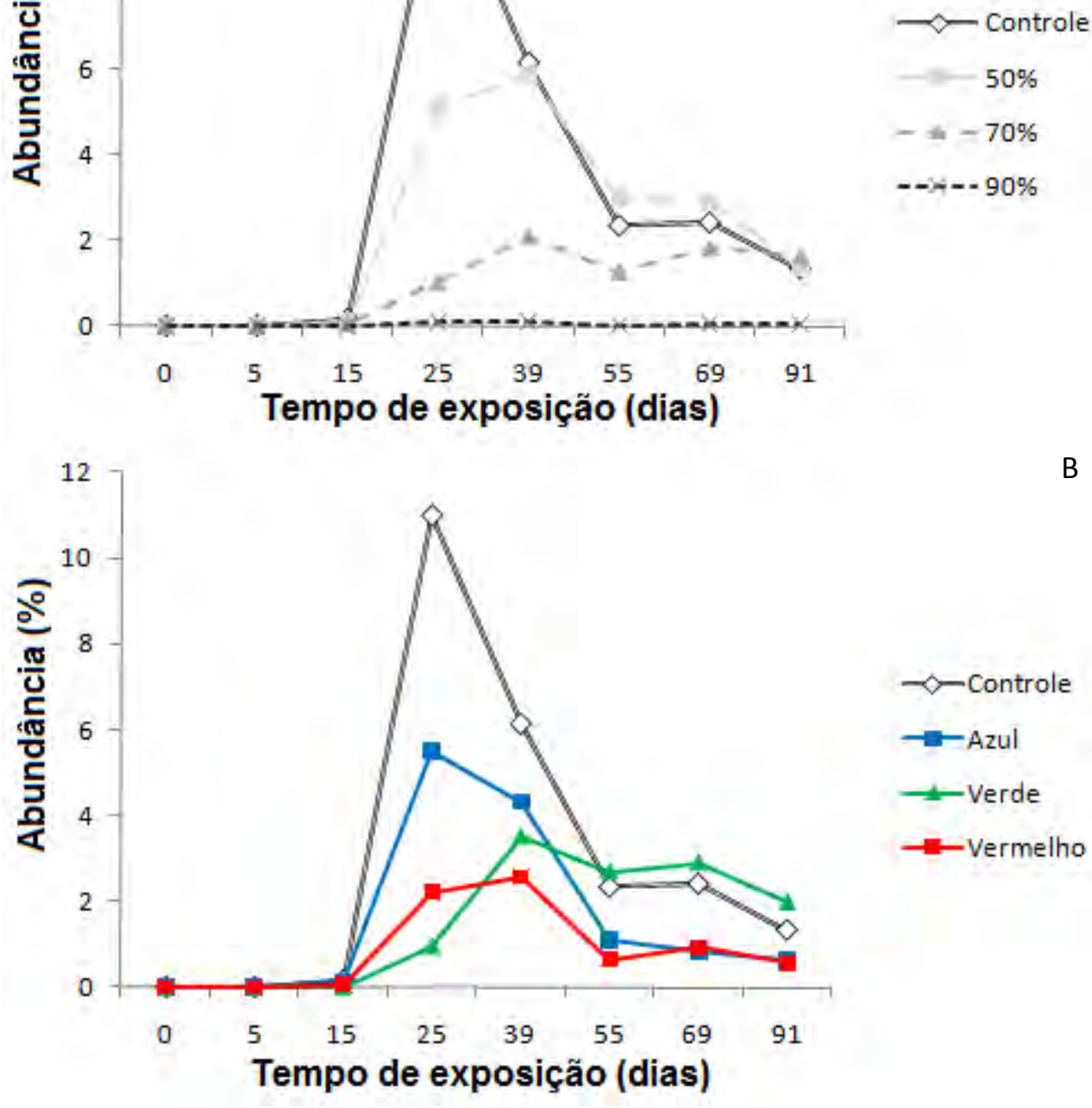

B

$\leadsto$ Controle

$\rightarrow$ Azul

$\perp$ Verde

$\rightarrow$-Vermelho

Figura 16. Variação dos valores de abundância da Divisão Chlorophyta ao longo do tempo (91 dias) diante dos tratamentos de luminosidade. (A) Tratamentos envolvendo a variação da quantidade da irradiância. (B) Tratamentos envolvendo a variação da qualidade da irradiância. 

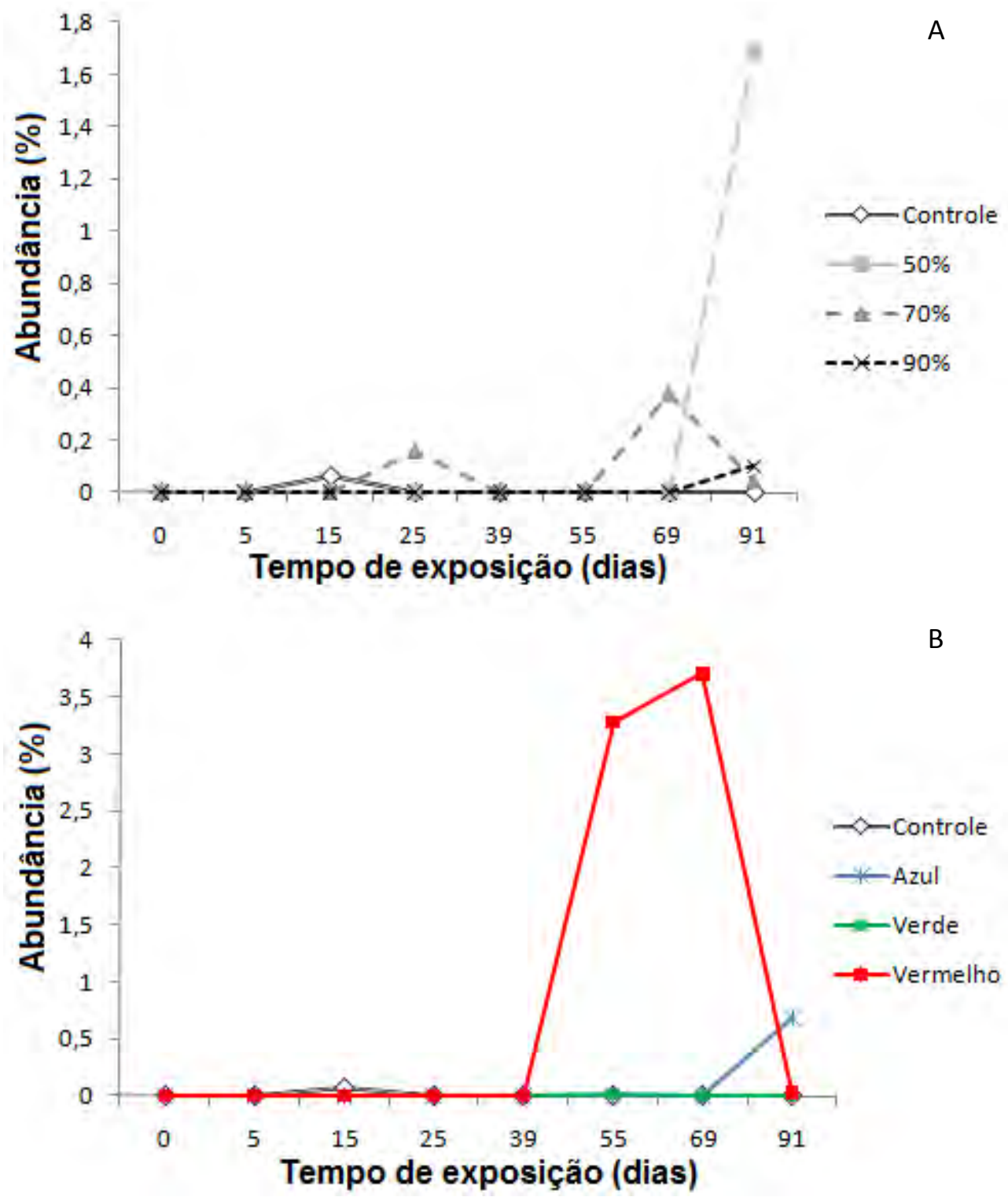

Figura 17. Variação dos valores de abundância da Divisão Rhodophyta ao longo do tempo (91 dias) diante dos tratamentos de luminosidade. (A) Tratamentos envolvendo a variação da quantidade da irradiância. (B) Tratamentos envolvendo a variação da qualidade da irradiância. 